\title{
4. LATE CENOZOIC RECORDS OF ICE-RAFTING AT ODP SITES 642, 643, AND 644, NORWEGIAN SEA: ONSET, CHRONOLOGY, AND CHARACTERISTICS OF GLACIAL/INTERGLACIAL FLUCTUATIONS ${ }^{1}$
}

\author{
Lawrence A. Krissek ${ }^{2}$
}

\begin{abstract}
The abundance and composition of the upper Cenozoic terrigenous coarse-sand fraction $(250 \mu \mathrm{m}-2 \mathrm{~mm})$ at ODP Sites 642,643 , and 644 were investigated to date the onset of significant ice-rafting in the Norwegian Sea, establish the regional chronology of ice-rafting, and determine the relative importance of global vs. regional controls on ice-rafting in this area. The first input of ice-rafted debris (IRD) occurs at approximately $2.9 \mathrm{Ma}$, with significant ice-rafting beginning at about 2.5 Ma. IRD abundances increase significantly in sediments younger than $0.9 \mathrm{Ma}$ at all three holes, indicating climatic deterioration in the late Pleistocene. Differences in the timing of this IRD increase between holes result from regional patterns of IRD supply and surface circulation. Variations in IRD sources and dispersal patterns may also explain the slightly higher background level of IRD abundance at Hole 642B, a seaward site.

Major peaks in the generalized IRD records from the Norwegian Sea are tentatively correlated to glacial stages or glacial-to-interglacial transitions in the globally defined oxygen isotope record. This correlation indicates the effect of global conditions on the regional climate of the Norwegian Sea, although the detailed IRD records at these sites are also affected by local/regional processes (e.g., circulation patterns and source area differences).
\end{abstract}

\section{INTRODUCTION}

During the past two decades, the late Cenozoic climatic history of the Northern Hemisphere has been investigated using a variety of marine data sets from piston cores and DSDP cores. These data sets have included microfossil abundances, microfossil assemblages, oxygen isotopic compositions of biogenic $\mathrm{CaCO}_{3}$, and abundances of terrigenous material transported into the ocean by icebergs (ice-rafted debris, or IRD). Records from the North Pacific Ocean have recently been discussed by Sancetta and Silvestri (1986), Morley (1986), Morley et al. (1987), and Krissek et al. (1985).

Studies of IRD in the North Atlantic and the Arctic oceans are generally of two types: stratigraphic studies, designed to determine the onset of IRD input and the chronology of IRD input at a particular geographic location; and paleogeographic studies, designed to identify the sources and dispersal patterns of IRD during particular intervals of the Late Cenozoic. From stratigraphic studies of IRD in the North Atlantic, a basic disagreement has emerged concerning the timing of first IRD input, which is also interpreted to reflect the onset of major Northern Hemisphere continental glaciation. Berggren (1972), Shor and Poore (1978), and Poore (1981) examined the IRD record at a number of DSDP sites in the North Atlantic and used biostratigraphic data to place the onset of IRD input at approximately 3.0 Ma. Backman (1979), Roberts et al. (1982), Schnitker (1982), Shackleton et al. (1984), Ruddiman et al. (1986), and Raymo et al. (1986), however, used data from other DSDP sites to propose that major IRD input began at 2.4 to $2.6 \mathrm{Ma}$. The latter proposal correlates well with the timing of IRD initiation in the North Pacific (Krissek et al., 1985; Carney, 1986), while an initiation prior to $2.5 \mathrm{Ma}$ is supported by the presence of IRD in older sediments of the Arctic Ocean (Herman and Hopkins, 1980; Margolis and Herman, 1980). All of the strati-

\footnotetext{
${ }^{1}$ Eldholm, O., Thiede, J., Taylor, E., et al., 1989. Proc. ODP, Sci. Results, 104: College Station, TX (Ocean Drilling Program).

2 Dept. of Geology and Mineralogy, The Ohio State University, Columbus, $\mathrm{OH} 43210$.
}

graphic studies identified variations in IRD importance moving upcore, which were interpreted to record glacial/interglacial fluctuations through the late Cenozoic. Most of those records also show a significant increase in maximum IRD abundance and IRD variability at 0.9 to $1.1 \mathrm{Ma}$; this increase is interpreted to record a major climatic deterioration at that time. DSDP cores recovered from the Norwegian-Greenland Sea (Leg 38; Talwani, Udintsev, et al., 1976) were plagued by poor core recovery and drilling disturbance, and were unsuitable for detailed stratigraphic investigation of the IRD record.

Paleogeographic studies have delineated the southern limits of IRD occurrence for the late Pliocene and the Pleistocene, demonstrating that significant ice-rafting during the late Pliocene was restricted to north of $45^{\circ} \mathrm{N}$., while Pleistocene ice-rafting extended well south of that latitude (Bramlette and Bradley, 1940; Conolly and Ewing, 1965; Ruddiman and McIntyre, 1976; Shor and Poore, 1978; Poore, 1981). The increase in area influenced by ice-rafting is interpreted to reflect climatic deterioration during the Pleistocene. Ruddiman and Glover (1972a, 1972b) and Ruddiman (1977a, 1977b) examined the distribution patterns of IRD for limited intervals during the Pleistocene, and used those patterns to infer paleocirculation patterns during glacials, interglacials, and transitions between glacials and interglacials. Of interest here is the difference in circulation patterns between the last glacial and the preceding interglacial, as shown by Ruddiman (1977b): circulation in the Norwegian Sea from 0.125 to $0.075 \mathrm{Ma}$ was dominated by northeasterly flow along the Norwegian coast and southwesterly flow in the western half of the Norwegian-Greenland Sea; circulation during the last glacial included a limited northeasterly flow along the coast, while southwesterly flow dominated the remainder of the Norwegian-Greenland Sea.

Kellogg $(1975,1976,1977,1980)$ examined circulation in the Norwegian-Greenland Sea during the past 150,000 to 450,000 yr, using coarse-fraction abundances (an IRD measure) and micropaleontologic data. Three major climatic and circulation modes were identified for that interval: the interglacial mode, characterized by a strong Norwegian Current and low IRD input; the glacial mode, characterized by a single sluggish, counterclockwise-flowing gyre, almost complete permanent ice cover, and high IRD input; and the transitional mode, characterized 
by a sluggish, counterclockwise-flowing gyre south of approximately $72^{\circ} \mathrm{N}$., seasonal-to-permanent ice cover, and variable IRD input. Kellogg $(1975,1976)$ concluded that true interglacial conditions had only occurred twice during the past $150,000 \mathrm{yr}$ : at present, and at approximately 125,000 to 110,000 y.b.p. Kel$\log (1977,1980)$ concluded that those two intervals were also the only occurrences of the interglacial mode during the past $450,000 \mathrm{yr}$, and that interglacial periods prior to 120,000 y.b.p. were characterized by the transitional circulation mode. Because the cores examined in the present study are aligned in a transect across the Norwegian margin, the changes in circulation outlined above may be important in explaining variability within the Norwegian Sea IRD records.

In summary, previous work has:

1. Concluded that abundances of continentally derived material, especially the sand-sized fraction, in deep-sea sediments of the North Atlantic and Arctic oceans do indicate relative importance of transport via ice-rafting at the time of deposition.

2. Established generalized chronologies of IRD abundance, which are interpreted to record several major events of Northern Hemisphere climatic deterioration during the late Cenozoic.

3. Concluded that general paleocirculation patterns in the North Atlantic Ocean and the Norwegian Sea have varied significantly during late Cenozoic glacial and interglacial periods.

Despite these efforts, however, several basic questions about late Cenozoic Northern Hemisphere paleoclimates require further investigation, and IRD data are especially suited to addressing these questions. Additional sediments with a potentially valuable IRD record were recovered during Leg 104 of the Ocean Drilling Program. As shown in Figure 1, Sites 642, 643, and 644 form a transect across the Norwegian continental margin. Because this location is intermediate between the North Atlantic Ocean and the Arctic Ocean, the IRD records from the Leg 104 sites provide valuable insight to paleoclimatic evolution in the major gateway between the Arctic Ocean and the Atlantic. Variations in the IRD records between Leg 104 sites may record changes in circulation patterns from glacial to interglacial intervals. In addition to their excellent location, the sedimentary sequences recovered during Leg 104 are well-suited to detailed IRD study because of high recovery rate $(98 \%$ in Hole $642 \mathrm{~B}$; $79 \%$ at $643 ; 94 \%$ at $644 \mathrm{~A}$; Eldholm, Thiede, Taylor, et al., 1987), limited coring disturbance, and reasonable paleomagnetic and biostratigraphic age control. As a result, this study was undertaken to address three basic questions:

1. Time of initiation of Northern Hemisphere glaciation and onset of ice-rafting. The intermediate location of these sites ensures valuable records for resolving the question of IRD onset before or after $2.5 \mathrm{Ma}$.

2. Chronology of late Cenozoic Northern Hemisphere glaciation and episodes of climatic deterioration. The intermediate location of these sites is again crucial for resolving discrepancies in the Arctic and the North Atlantic records.

3. The importance of hemispheric vs. local/regional controls on the Norwegian Sea IRD records. Synchronous changes in the IRD records at these sites will be interpreted to reflect large-scale (global or hemispheric) controls, while differences in IRD records between sites will be interpreted to record regional or local effects (e.g., changes in surface circulation patterns).

\section{GENERAL LITHOSTRATIGRAPHY AND AGE CONTROL}

The lithostratigraphies of Sites 642,643 , and 644 are described in detail by Eldholm, Thiede, Taylor, et al. (1987). The youngest lithostratigraphic unit (Unit I) is generally similar at each site, consisting of dark, carbonate-poor glacial muds to sandy muds interbedded with light, carbonate-rich interglacial muds to sandy (foraminifer-rich) muds. At Hole 642B, Unit I extends to 65 meters below sea floor (mbsf), and is underlain by $25 \mathrm{~m}$ of Unit IIA, which is composed of nannofossil oozes with minor diatom-nannofossil oozes and muds. Unit IIA is late Miocene(?) to late Pliocene in age, while Unit I is late Pliocene to Holocene in age. At Hole 643, Unit I extends to $50 \mathrm{mbsf}$, contains numerous small slumps and unconformities, and is Pleistocene to Holocene in age. At Hole 644A, Unit I extends to 231 mbsf, and is Pliocene to Holocene in age.

More detailed age control for these units is provided by magnetostratigraphy (Bleil, this volume). Reversal boundaries identified in the Pliocene-to-Holocene sections of these holes are summarized in Table 1, together with sedimentation rates calculated assuming constant rates of sedimentation between reversal boundaries. While the assumption of constant sedimentation rates is probably incorrect in detail (Henrich, this volume), these values provide the best age-depth model presently available (see Jansen et al. (this volume) for a discussion of problems complicating the development of a more detailed age-depth model).

\section{METHODS AND ANALYSES}

Samples for IRD analysis were taken at Holes 642B, 643A, and $644 \mathrm{~A}$, with major efforts focused on Holes 642B and 644A. Sampling at Hole $643 \mathrm{~A}$ was terminated within Unit I because of sedimentologic evidence of slumping and the presence of several hiatuses (Eldholm, Thiede, Taylor, et al., 1987; Bleil, this volume). Samples were taken on board ship at the sampling intervals (in $\mathrm{cm}$ ) and the depth ranges listed in Table 2. The average sampling interval in years is also given in Table 2 , and was determined using sedimentation rates based on paleomagnetically derived dates within the sampled intervals (Table 1; Bleil, this volume).

Sample spacing and the total intervals sampled were limited by shipboard constraints. Samples were taken at regular intervals without prior knowledge of sedimentation rates, so that the average sampling interval (in years) changes significantly downcore at Hole 642B. Future studies will develop IRD records for these sites using constant sampling intervals (in years) throughout the intervals studied. A total of 287 samples were analyzed from Hole 642B, 65 samples from Hole 643A, and 210 samples from Hole 644A. Average sampling intervals range from approximately 3.5 to $40 \mathrm{k} . \mathrm{y}$., with shortest sampling intervals at Holes $642 \mathrm{~B}$ and $644 \mathrm{~A}$.

To conservatively estimate the abundance of IRD in these samples, the $250-\mu \mathrm{m}$ to $2-\mathrm{mm}$ grain-size fraction was chosen for analysis. Each sample was freeze-dried, weighed, disaggregated ultrasonically, and wetsieved at $250 \mu \mathrm{m}$ and $2 \mathrm{~mm}$. The coarse-sand fraction was then dried, weighed, and examined under a binocular microscope to qualitatively determine the abundances of various sediment components. The major components present were foraminifers (up to $100 \%$ of some samples), pyritized burrows (up to $100 \%$ of some samples), and clastic grains; the latter form the IRD. To remove the non-IRD components from the coarse-sand fraction, each sample was subjected to two additional treatments: (a) $1 \mathrm{~N} \mathrm{HCl}$ was added to dissolve biogenic carbonate, and (b) a density separation was performed using sodium polytungstate (specific gravity $=3.0$ ), to remove authigenic pyrite. The terrigenous component of the coarse-sand fraction was then dried and weighed, and that weight was used to calculate the abundance of coarse-sand IRD in the total original sample. A minor portion of the IRD in some samples was composed of carbonate rock fragments, which were destroyed during the acid treatment. Within the coarse-sand fraction, however, most of the IRD ( $>95 \%)$ was composed of quartz, feldspar, and plutonic, volcanic, and metamorphic rock fragments, so the errors introduced by destroying the carbonate rock fragments are considered minor. Sample ages were calculated using position below sea floor and average sedimentation rates determined by paleomagnetic datums (see Table 1; Bleil, this volume).

\section{DATA}

The IRD abundances for Holes 642B, 643A, and 644A are tabulated in Appendixes A, B, and C, respectively. Porosity and 


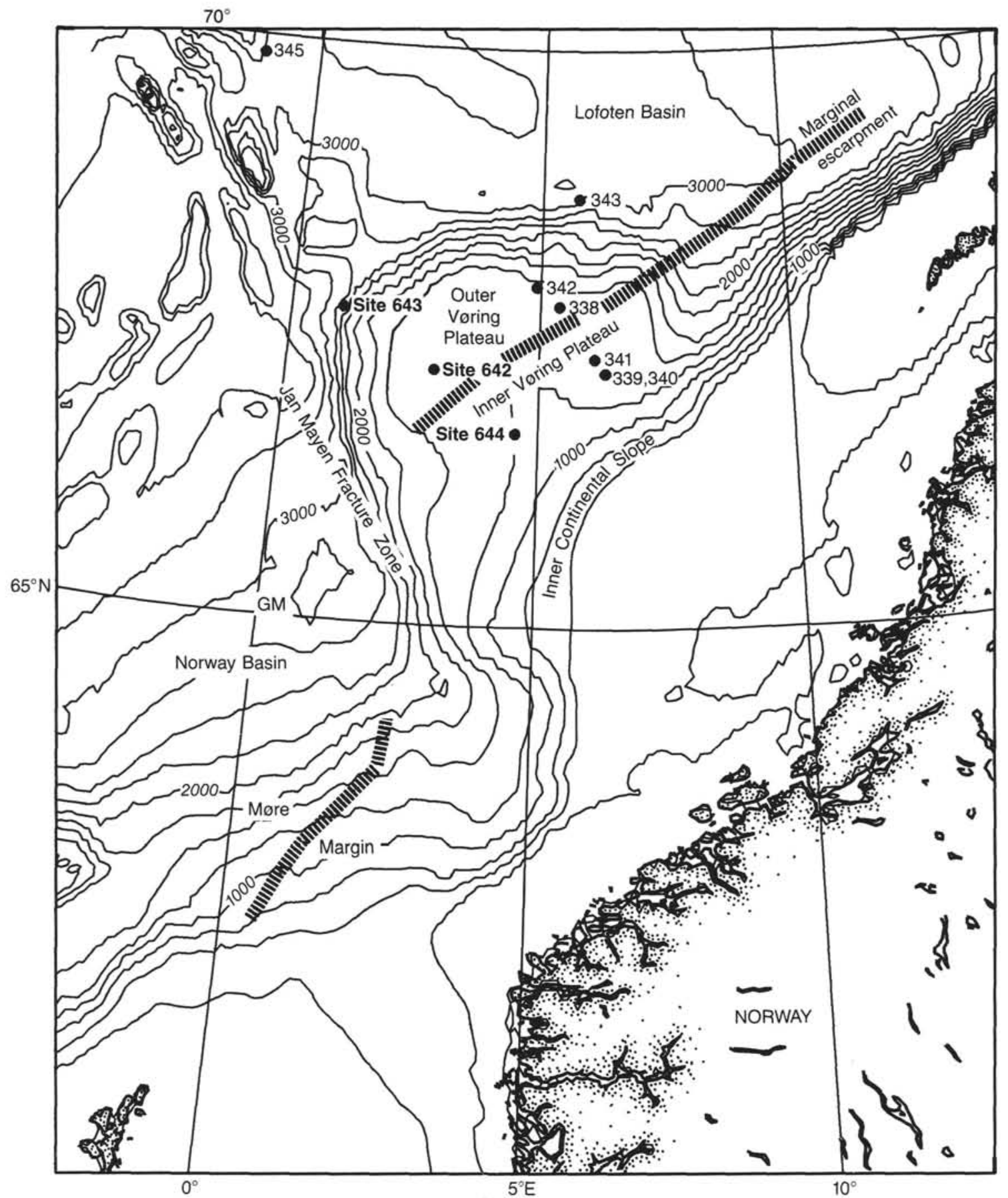

Figure 1. Location map of ODP Sites 642, 643, and 644, and bathymetry of the Vøring Plateau region of the Norwegian-Greenland Sea. Contours, $250 \mathrm{~m}$.

bulk density data for these cores are given in Pittenger, et al. (this volume) and in Eldholm, Thiede, Taylor, et al. (1987). Relative abundance data for the coarse-sand IRD (weight $\%$ of the coarse-sand IRD relative to the total sample weight) at Holes 642B, 643, and 644A are plotted as a function of age in Figures 2,3 , and 4 , respectively.

\section{DISCUSSION}

The IRD records determined for ODP Holes 642B, 643A, and 644A each show significant variations in abundance through the late Cenozoic, reflecting glacial/interglacial fluctuations in a general way. Each record, however, has distinctive characteristics, which complicate the development of a regional paleocli- matic history. To examine these data fully, this discussion will consist of three parts: (a) a discussion of individual IRD records, (b) a comparison of the IRD records from these three holes in the Norwegian Sea, and (c) a comparison of this Norwegian Sea record to the global oxygen isotopic record of late Cenozoic paleoclimates.

\section{IRD Records at ODP Holes 642B, 643A, and 644A}

\section{Hole $642 B$}

The IRD record at Hole 642B (Fig. 2; Appendix A) is the longest of the three records determined in this study, extending to approximately 3.9 Ma. Because of the length of this record, it 
Table 1. Paleomagnetic boundaries (Bleil, this volume) used to assign ages in the uppermost sediments at Holes 642B, $643 \mathrm{~A}$, and $644 \mathrm{~A}$. Sedimentation rates calculated assuming constant rate of sedimentation between paleomagnetic boundaries.

\begin{tabular}{|c|c|c|c|}
\hline Boundary & $\begin{array}{l}\text { Age } \\
(\mathrm{Ma})\end{array}$ & $\begin{array}{l}\text { Depth } \\
\text { (mbsf) }\end{array}$ & $\begin{array}{c}\text { Sedimentation } \\
\text { Rate } \\
(\mathrm{cm} / \mathrm{k} . \mathrm{y} .)\end{array}$ \\
\hline \multicolumn{4}{|c|}{ Hole 642B } \\
\hline $\mathrm{C} 1 \mathrm{~N}-1$ & & 37.11 & 5.1 \\
\hline CIR-1 & 0.73 & 37.40 & \\
\hline CIR-1 & 0.91 & 41.81 & 2.6 \\
\hline $\mathrm{C} 1 \mathrm{~N}-2$ & & 42.11 & \multirow{2}{*}{4.9} \\
\hline $\mathrm{C}$ IN-2 & 0.98 & 45.11 & \\
\hline CIR-2 & & 45.71 & 1.1 \\
\hline CIR-2 & 1.66 & $\begin{array}{l}52.59 \\
52.90\end{array}$ & \multirow[b]{2}{*}{1.1} \\
\hline $\begin{array}{l}\mathrm{C} 2 \mathrm{~N} \\
\mathrm{C} 2 \mathrm{~N}\end{array}$ & & $\begin{array}{l}52.90 \\
54.99\end{array}$ & \\
\hline$C 2 R$ & 1.88 & 55.30 & \multirow{2}{*}{1.6} \\
\hline $\mathrm{C} 2 \mathrm{R}$ & 2.47 & 64.50 & \\
\hline $\mathrm{C} 2 \mathrm{AN}-1$ & & 64.80 & \multirow{2}{*}{0.5} \\
\hline C2AN-1 & 2.92 & 66.81 & \\
\hline C2AR-1 & & 67.11 & \multirow[t]{2}{*}{0.5} \\
\hline C2AR-2 & 3.18 & 68.01 & \\
\hline C2AN-3 & & 68.31 & \multirow{2}{*}{0.8} \\
\hline $\mathrm{C} 2 \mathrm{AN}-3$ & 3.40 & 69.87 & \\
\hline C2AR-3 & & 70.11 & \multirow{3}{*}{1.2} \\
\hline C2AR-3 & 3.88 & 75.96 & \\
\hline $\mathrm{C} 3 \mathrm{~N}-1$ & & 75.99 & \\
\hline \multicolumn{4}{|c|}{ Hole $643 \mathrm{~A}$} \\
\hline $\mathrm{C} 1 \mathrm{~N}-1$ & 0.73 & 26.36 & 3.6 \\
\hline C1R-1 & & 26.76 & \multirow{2}{*}{1.9} \\
\hline CIR-1 & 0.91 & 29.76 & \\
\hline $\mathrm{C} 1 \mathrm{~N}-2$ & & 30.12 & \multirow{3}{*}{3.7} \\
\hline $\mathrm{C} 1 \mathrm{~N}-2$ & 0.98 & 32.36 & \\
\hline CIR-2 & & 32.76 & \\
\hline \multicolumn{4}{|c|}{ Hole 644A } \\
\hline $\mathrm{C} 1 \mathrm{~N}-1$ & 0.73 & 80.84 & 11.4 \\
\hline C1R-1 & 0.15 & 86.06 & \multirow{2}{*}{11.4} \\
\hline C1R-1 & 0.91 & 203.72 & \\
\hline $\mathrm{C} 1 \mathrm{~N}-2$ & 0.91 & 104.06 & \multirow[t]{2}{*}{10.4} \\
\hline $\mathrm{CIN}-2$ & 0.98 & 110.56 & \\
\hline C1R-2 & & 111.79 & 8.2 \\
\hline
\end{tabular}

Table 2. Sampling intervals and total intervals sampled at Leg 104 sites for analysis of icerafted debris.

\begin{tabular}{|c|c|c|c|c|}
\hline \multirow[b]{2}{*}{ Hole } & \multicolumn{2}{|c|}{$\begin{array}{l}\text { Total } \\
\text { interval sampled }\end{array}$} & \multicolumn{2}{|c|}{$\begin{array}{c}\text { Average } \\
\text { sampling } \\
\text { interval }\end{array}$} \\
\hline & $\begin{array}{l}\text { Depth } \\
\text { (mbsf) }\end{array}$ & $\begin{array}{l}\text { Age } \\
\text { (Ma) }\end{array}$ & $\begin{array}{l}\text { Depth } \\
\text { (cm) }\end{array}$ & $\begin{array}{l}\text { Time } \\
\text { (k.y.) }\end{array}$ \\
\hline $642 B$ & $0-37.26$ & $0-0.73$ & 20 & 3.5 \\
\hline 642B & $37.26-41.96$ & $0.73-0.91$ & 20 & 7.7 \\
\hline $642 B$ & $41.96-45.41$ & $0.91-0.98$ & 20 & 4.1 \\
\hline $642 B$ & $45.41-52.75$ & $0.98-1.66$ & 20 & 18.2 \\
\hline $642 B$ & $52.75-55.16$ & $1.66-1.88$ & 20 & 18.2 \\
\hline $642 B$ & $55.16-64.65$ & $1.88-2.47$ & 20 & 12.5 \\
\hline $642 B$ & $64.65-66.96$ & $2.47-2.92$ & 20 & 40.0 \\
\hline $642 B$ & $66.96-68.16$ & $2.92-3.18$ & 20 & 40.0 \\
\hline $642 B$ & $68.16-69.99$ & $3.18-3.40$ & 20 & 25.0 \\
\hline $642 B$ & $69.99-75.97$ & $3.40-3.88$ & 20 & 16.7 \\
\hline $643 \mathrm{~A}$ & $0-26.56$ & $0-0.73$ & 50 & 13.9 \\
\hline $643 \mathrm{~A}$ & $26.56-29.94$ & $0.73-0.91$ & 50 & 26.3 \\
\hline $643 \mathrm{~A}$ & $29.94-33.13$ & $0.91-1.00$ & 50 & 13.5 \\
\hline $644 \mathrm{~A}$ & $0-83.45$ & $0-0.73$ & 50 & 4.4 \\
\hline $644 \mathrm{~A}$ & $83.45-103.99$ & $0.73-0.91$ & 50 & 4.4 \\
\hline $644 \mathrm{~A}$ & $103.99-111.18$ & $0.91-0.98$ & 50 & 4.8 \\
\hline $644 \mathrm{~A}$ & $111.18-128.02$ & $0.98-1.19$ & 50 & 6.1 \\
\hline
\end{tabular}

is the only one suitable for dating the onset of IRD input to the Norwegian Sea. On the basis of consistent patterns of variation, this record is subdivided into six parts: (a) older than $2.88 \mathrm{Ma}$, (b) 2.88 to $2.45 \mathrm{Ma}$, (c) 2.45 to $2.33 \mathrm{Ma}$, (d) 2.33 to $2.00 \mathrm{Ma}$, (e) 2.00 to $0.84 \mathrm{Ma}$, and (f) younger than $0.84 \mathrm{Ma}$. As shown in Figure 2, the first input of IRD occurs at approximately 2.88 $\mathrm{Ma}$, with several apparent IRD peaks defined by single data points between 2.45 and $2.88 \mathrm{Ma}$. Because these peaks are defined by single data points, however, they are interpreted as indicators of only minor IRD input; demonstration of significant IRD input at this time will require additional sampling to more clearly define these peaks. Significant IRD input becomes apparent at approximately $2.45 \mathrm{Ma}$, with the appearance of IRD abundance peaks that are defined by multiple data points. This IRD increase is not an artifact of decreased dilution by other components, since sedimentation rates actually increased at this time (Table 1). Jansen et al. (this volume) use terrigenous coarsefraction abundances and the onset of glaciomarine lithologies (Henrich, this volume) to place the onset of ice-rafting at approximately $2.56 \mathrm{Ma}$ at both Site 642 and Site 644, with a subsequent increase in ice-rafting at approximately $2.4 \mathrm{Ma}$.

A major pulse of IRD input occurs from 2.45 to approximately $2.33 \mathrm{Ma}$, and is followed by a period of low IRD input, which lasts until approximately $2.00 \mathrm{Ma}$. A similar transition to major ice influence in the North Atlantic has been described by Ruddiman et al. (1986b) and Raymo and Ruddiman (1987). The latter recognized a gradual increase in ice influence from 3.2 to $2.1 \mathrm{Ma}$, with abrupt large IRD influxes at 2.40 and $2.36 \mathrm{Ma}$, followed by a break in IRD influx until approximately $2.15 \mathrm{Ma}$. These similarities suggest that the development of glacial influence is consistent throughout this sector of the Northern Hemisphere, and that limited IRD influx did occur prior to $2.5 \mathrm{Ma}$. The onset of major IRD input, however, occurs at approximately $2.5 \mathrm{Ma}$.

Between 2.0 and $1.0 \mathrm{Ma}$, maximum IRD abundances at Hole $642 \mathrm{~B}$ range from 2.0 to $3.5 \%$, with minimum IRD values of $0 \%$. Several IRD peaks are defined by multiple data points in this interval, but these may represent aliasing of shorter term fluctuations by widely spaced data points. As a result, the IRD record from this interval cannot be interpreted in detail. It is interesting to note, however, that the maximum values observed between 2.0 and 1.0 Ma are approximately the same as the max- 


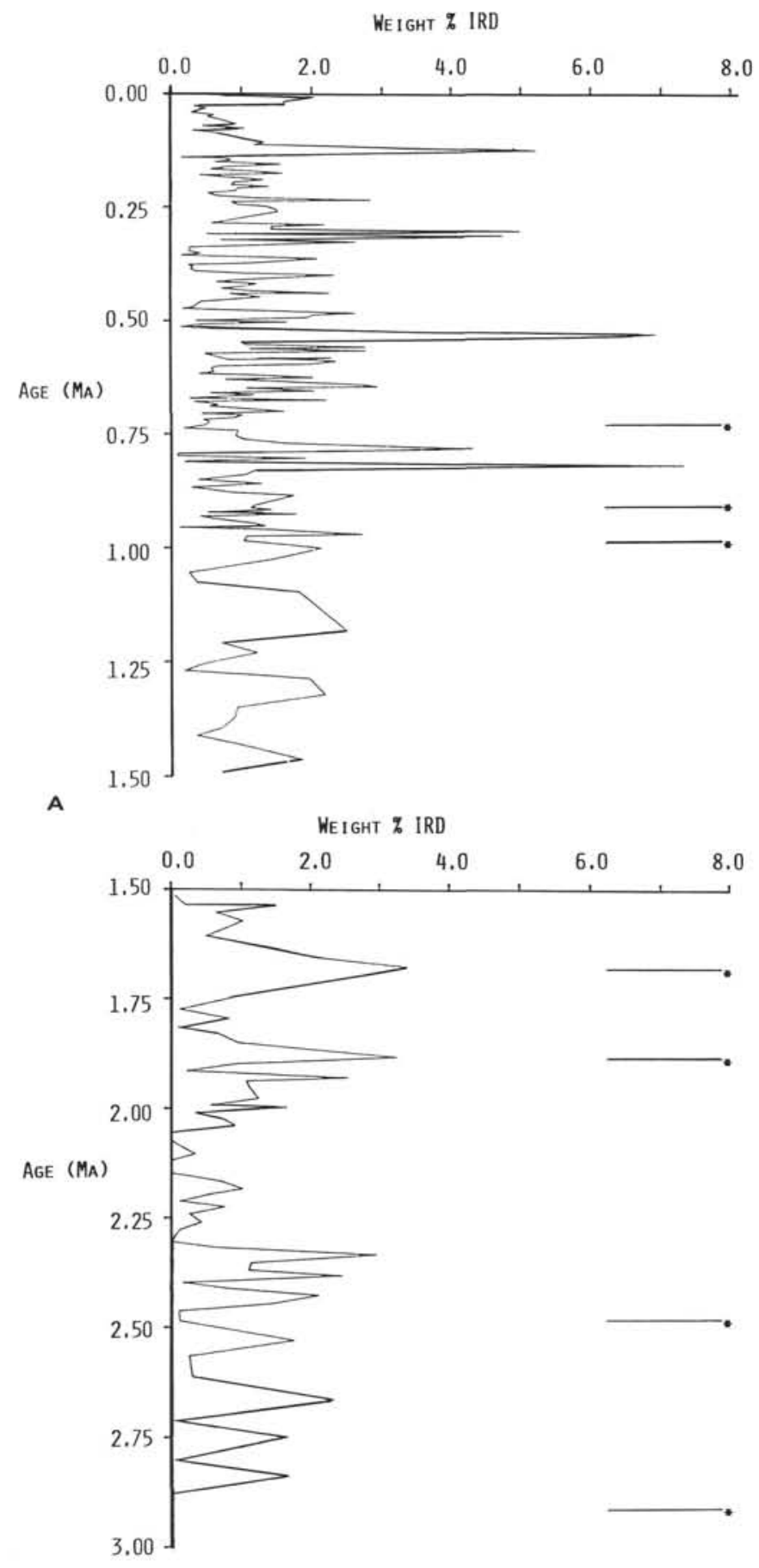

B

Figure 2. A and B. Abundance of coarse-sand IRD in samples from ODP Hole 642B, plotted as a function of age. No coarse-sand IRD occurs in sediments older than $2.9 \mathrm{Ma}$, so no results are plotted for sediments older than that. ---* indicates position of paleomagnetic boundary used for age assignments (Table 1).

imum values observed between 1.0 and $0.84 \mathrm{Ma}$, where sample spacing is much closer and short-term fluctuations are clearly defined. For this reason, a preliminary hypothesis proposes that the IRD record at Hole $642 \mathrm{~B}$ from 2.0 to $1.0 \mathrm{Ma}$ resembles that observed from 1.0 to $0.84 \mathrm{Ma}$. Analysis of more samples from the 2.0- to $1.0-\mathrm{Ma}$ interval will test this hypothesis in the future.

The IRD record at Hole $642 \mathrm{~B}$ changes significantly at approximately $0.84 \mathrm{Ma}$, with the first IRD abundance greater than $4 \%$. This IRD increase is not caused by a decrease in dilution by

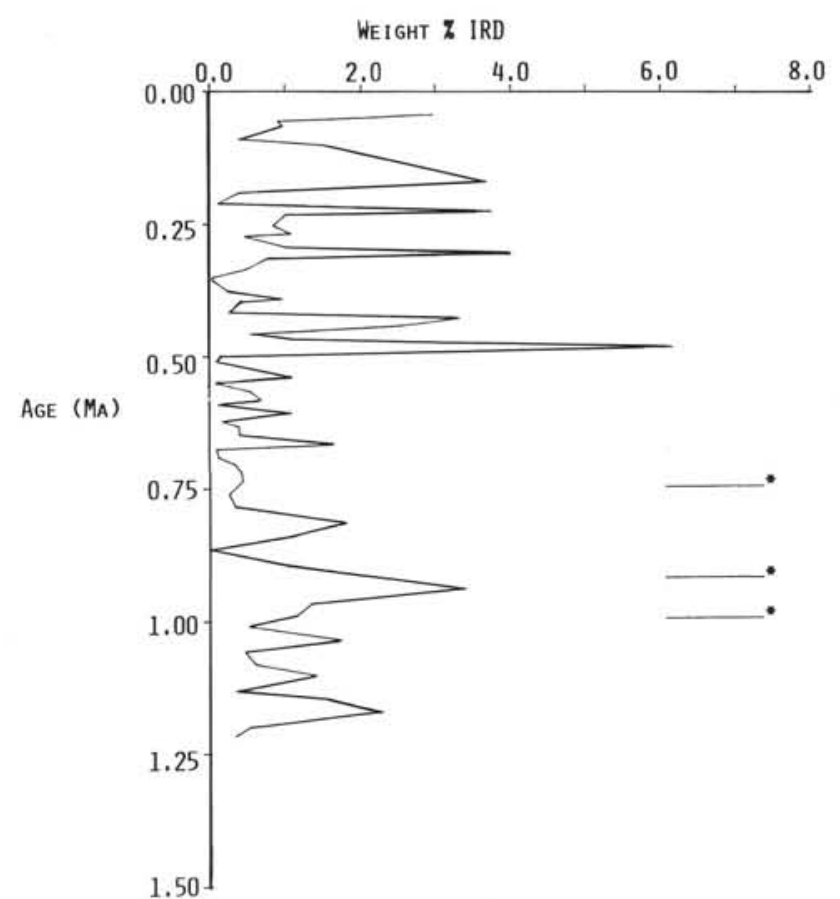

Figure 3. Abundance of coarse-sand IRD in samples from ODP Hole $643 \mathrm{~A}$, plotted as a function of age. ---* indicates position of paleomagnetic boundary used for age assignments (Table 1).

other components, because sedimentation rates increase in younger sediments (Table 1). Four peaks of similar magnitude $(>4 \%)$ occur in sediments younger than $0.84 \mathrm{Ma}$, superimposed on fluctuations that appear quite similar to those found between 1.0 and $0.83 \mathrm{Ma}$. The timing and the magnitude of this major IRD increase suggests that it results from the major climatic deterioration observed in other Northern Hemisphere data sets at about this time. The apparent continuity of the smaller fluctuations from at least $1.0 \mathrm{Ma}$ suggests that a basic pattern of climatic change was well-developed prior to $0.84 \mathrm{Ma}$, and that this pattern was periodically intensified after $0.84 \mathrm{Ma}$.

\section{Hole 643A}

The IRD record at Hole 643A (Fig. 3; Appendix B) is the poorest of the three records determined here, because of wide sample spacing, limited age control, and the effects of numerous slumps (see Eldholm, Thiede, Taylor, et al., 1987, for a discussion of this hole). As a result, this record provides less detailed information than the records at Holes 642B and 644A. The record at Hole 643A contains three intervals with consistent styles of variation: (a) older than $0.78 \mathrm{Ma}$, (b) 0.78 to $0.50 \mathrm{Ma}$, and (c) younger than $0.50 \mathrm{Ma}$. The oldest portion of this record (older than $0.78 \mathrm{Ma}$ ) has maximum IRD abundances greater than $1.5 \%$, minimum values of approximately $0.5 \%$, and contains relatively broad peaks. The middle portion of the record has maxima less than $1.5 \%$, minima of $0 \%$, and single-point peaks. The youngest part of the IRD record at Hole 643A is dominated by single-point peaks with maxima of $3 \%$ or more; the increased IRD abundance in the youngest sediments again suggests climatic deterioration, but the limited record available at this hole precludes detailed interpretation of the timing and the nature of that deterioration.

\section{Hole 644A}

The IRD record determined for Hole 644A (Fig. 4; Appendix C) extends to approximately $1.19 \mathrm{Ma}$; because of its high sedi- 


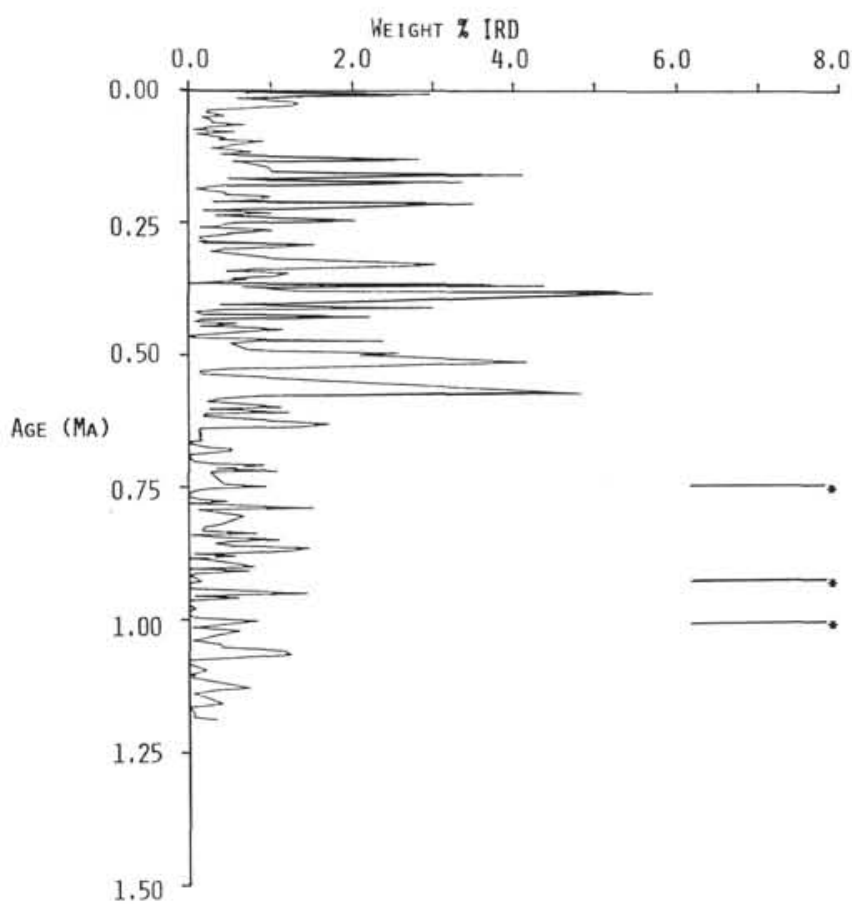

Figure 4. Abundance of coarse-sand IRD in samples from ODP Hole $644 \mathrm{~A}$, plotted as a function of age. -..* indicates position of paleomagnetic boundary used for age assignments (Table 1).

mentation rate and its landward position in the Leg 104 transect, this site provides a very detailed history of ice-rafting importance through the Pleistocene. Sedimentation rates (Table 1) are approximately constant through this section, so that variations in IRD abundances are not an artifact of varying dilution by other sedimentary components. The IRD record at Hole $644 \mathrm{~A}$ can be subdivided into two intervals with consistent patterns of variation: (a) older than approximately $0.56 \mathrm{Ma}$, and (b) younger than $0.56 \mathrm{Ma}$. The older portion of the record is characterized by a low-amplitude signal, with maxima less than $1.6 \%$ IRD, while the record since $0.56 \mathrm{Ma}$ contains numerous peaks defined by 3.0 to $6.0 \%$ IRD. The increased IRD abundance in the younger sediments again supports an interpretation of climatic deterioration during the Pleistocene, although this change occurs at a younger level at Hole 644A than at other locations in the Northern Hemisphere. This difference in timing may provide important information about changes in regional paleocirculation and/or glacial extent during the late Cenozoic.

\section{IRD Record of the Norwegian Sea: Regional Synthesis}

To examine the regional response of the Norwegian Sea to late Cenozoic climatic fluctuations, the IRD records from these three holes have been examined for stratigraphically equivalent variations. This regional synthesis is limited to the past $1.0 \mathrm{~m} . \mathrm{y}$. by the length of the record from Hole $644 \mathrm{~A}$, and concentrates on the records from Holes $642 \mathrm{~B}$ and $644 \mathrm{~A}$ because of the poor quality of the IRD record presently available from Hole 643A.

In spite of the geographic proximity of the three holes examined in this study, their IRD records show significant lateral variations (compare intervals of equivalent age from Figures 2, 3, and 4). Differences between the record at Hole 643A and the records at Holes 642B and 644A at least partly reflect differences in the sampling intervals used. The records from Holes 642B and $644 \mathrm{~A}$ were developed with approximately the same sampling interval (see Table 2), but also show significant differences, as emphasized in Figure 5. These differences record real changes in IRD input, suggesting that IRD sources and paleocirculation patterns changed rapidly away from the Norwegian continental margin.

The records from both Hole 642B and Hole 644A show low IRD input prior to $0.84 \mathrm{Ma}$. IRD abundances in this interval are slightly higher at Hole 642B, the more seaward of these two locations. The increase in IRD abundance away from the Norwegian coast may reflect decreased dilution in environments with lower sedimentation rates (Table 1), but may also record increased IRD input at more seaward locations. The seaward increase in IRD input may occur because of southwesterly flow during both glacial and interglacial episodes, as proposed for more recent conditions by Ruddiman (1977b) and Kellogg (1977, 1980); with this circulation pattern, high-latitude regions could supply IRD to Hole 642B while the more landward (644A) location was periodically influenced by warmer waters from the southwest. Such a circulation pattern could also explain the diachroneity of the upper Pleistocene IRD increase at these two sites. In such a model, the major IRD influx to Hole 642B at 0.77 to $0.84 \mathrm{Ma}$ was derived from glacial sources located well north of the Leg 104 transect, while the major IRD increase to Hole $644 \mathrm{~A}$ at approximately $0.56 \mathrm{Ma}$ records a younger southward expansion of major continental glaciations.

At both Hole $642 \mathrm{~B}$ and Hole $644 \mathrm{~A}$, the IRD record since $0.84 \mathrm{Ma}$ consists of two major components: (a) a background signal, similar to the pre-0.84 Ma record at each site, and (b) a superimposed signal of occasional, high-amplitude IRD peaks. As discussed previously, the background signal at Hole $642 \mathrm{~B}$ is generally greater than the background IRD input at Hole 644A, probably reflecting the persistence of iceberg sources north of $67^{\circ} \mathrm{N}$ and the persistence of southerly circulation at the more seaward location. The superimposed, high-amplitude component is more common at Hole $644 \mathrm{~A}$ than at Hole 642B in sediments younger than $0.56 \mathrm{Ma}$, suggesting that IRD input was increased close to the continent after the climatic deterioration observed at 0.7 to $0.9 \mathrm{Ma}$. Following that climatic deterioration, continental glaciations may have extended well south of $67^{\circ} \mathrm{N}$, providing iceberg sources for Site 644 . Icebergs originating east or south of the study area may have encountered relatively warm waters in a weak remnant of the northerly coastal current, resulting in enhanced melting and IRD release at more shoreward locations. The greater number of IRD peaks at Hole 644A since $0.56 \mathrm{Ma}$ may then reflect two influences: enhanced iceberg meltout because of advected warm waters, and greater sensitivity of the more southerly glaciers (which appear to have served as the major IRD source to Hole 644A) to climatic variation.

Direct correlations of IRD peaks between Hole 642B and Hole $644 \mathrm{~A}$ are complicated by the greater number of IRD peaks at Hole $644 \mathrm{~A}$ and by the limited number of paleomagnetic datums available for absolute age control (Table 1). In sediments younger than $0.56 \mathrm{Ma}$, each record contains three general maxima: 0.52 to $0.57,0.29$ to 0.33 , and 0.11 to $0.14 \mathrm{Ma}$ at Hole $642 \mathrm{~B}$, and 0.48 to $0.56,0.31$ to 0.40 , and 0.14 to $0.17 \mathrm{Ma}$ at Hole 644A. Given the oversimplification inherent in using constant rates of sedimentation to assign these ages, these maxima may indicate three major episodes of increased ice-rafting during the late Pleistocene. The youngest of these increases may reflect deposition immediately prior to the Eemian interglacial, which both Kellogg $(1975,1976)$ and Ruddiman (1977a, 1977b) identified as a time of vigorous northward flow by the Norwegian Current. The two older IRD maxima at these sites must reflect local or regional variability in IRD input during the "glacial" and "transitional" climatic modes of Kellogg $(1977,1980)$. The effects of environmental variability at Sites 642 and 644 can also be observed in the oxygen isotope and carbonate abundance records from these sites (Jansen et al., this volume), 


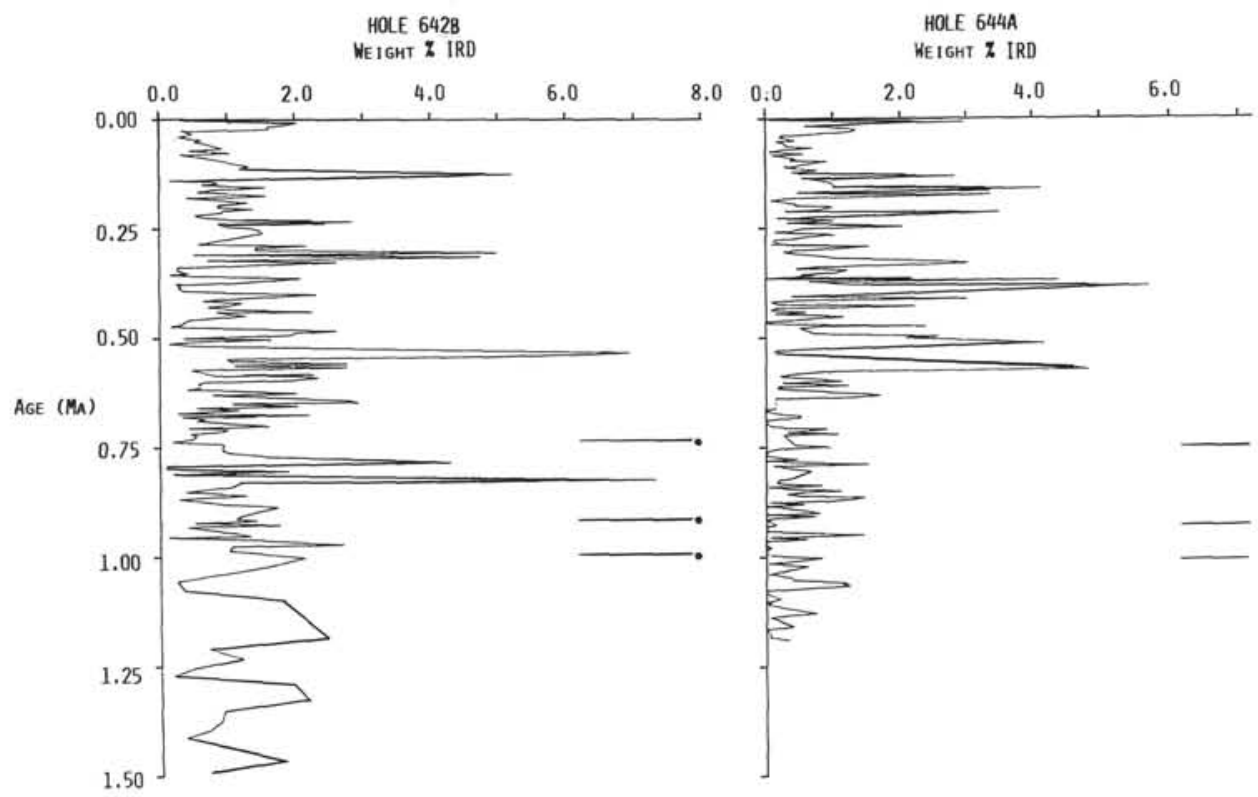

Figure 5. Comparison of IRD abundances at Holes 642B and 644A over the past $1.5 \mathrm{~m} . \mathrm{y}$. The record from Hole 643A is not included in this comparison because of its wide sample spacing and poor age control.

where low-salinity influences and dissolution events degrade records normally used for high-resolution age assignments.

This synthesis of the IRD records from Hole 642B and Hole $644 \mathrm{~A}$ has used geographically distinct IRD sources and landward/seaward changes in circulation to explain the diachronous nature of the major late Pleistocene IRD increase and the seaward increase in IRD abundance. The temporal relationships of major Pleistocene IRD maxima appear to record a combination of large-scale (hemispheric climate) and local/regional (circulation pattern) controls. More detailed interpretations will require better age control at these holes and integration of these data with locally-derived oxygen isotope curves. The model proposed here is internally consistent, however, and generally agrees with published studies of glacial/interglacial circulation in the Norwegian Sea (Ruddiman, 1977b; Kellogg, 1980).

\section{Comparison: Norwegian Sea IRD and Global Oxygen Isotope Records}

Globally averaged records of the oxygen isotopic composition in tests of fossil foraminifers are generally thought to reflect changes in the isotopic composition of ocean water, which varies with the volume of continental ice (Imbrie et al., 1984). Total continental ice volume is strongly influenced by global climate, while local climate and local ice volume have major impacts on the local production of IRD. Because the oxygen isotope and IRD records are both climatic indicators, but respond to different scales of variation, a comparison of the two reveals the response of the Norwegian Sea to global climatic forcing. The comparison presented here is preliminary; the major limitations on the IRD record presently available are variable sample spacing, first-order approximation of sediment ages, and the use of IRD abundances instead of mass accumulation rates. Future work will develop the IRD records necessary for more accurate comparison to the global oxygen isotope record.

The global oxygen isotope record of Imbrie et al. (1984) is used for this preliminary comparison. To account for the limited age control and lateral variability of the IRD records and to allow for a conservative comparison, the IRD records for these three holes were generalized using the following criteria:
1. An abundance value of $1 \%$ IRD was defined as baseline; inspection of Figures 2, 3, and 4 shows that this is a reasonable choice for discriminating peaks from nonpeaks on these records.

2. The original IRD abundance data (Appendixes A, B, and C) were visually scanned for groups of three or more consecutive data points with values greater than $1 \%$; mathematical filtering/averaging techniques could not be applied because of nonuniform sample spacing.

3. The sample spacing within each group of IRD-rich samples identified in step 2 was examined. If consecutive samples were closely spaced (within $10 \mathrm{k} . \mathrm{y}$. ), then the group was classified as an IRD peak and plotted in Figure 6. If spacing between consecutive samples exceeded $10 \mathrm{k}$.y., then the group was not considered to represent an IRD peak, and probably developed as a result of signal aliasing.

The generalized IRD records for Holes 642B, 643A, and $644 \mathrm{~A}$ are plotted in Figure 6, with the oxygen isotope stratigraphy of Imbrie et al. (1984) added for comparison. Within the limitations of our age control, which may be significant, most of the generalized IRD peaks either occur during a glacial stage or overlap slightly from a glacial into an interglacial stage. This general distribution supports the interpretation that major IRD production occurs during times of increased ice volume, but also suggests that significant IRD input can occur during glacial-to-interglacial transitions. The latter inputs may be important for developing parts of the IRD record in the Norwegian Sea, such as the pre-Eemian maximum described previously.

Several of the glacial stages identified in the oxygen isotope record are not represented by peaks in any of the generalized IRD records. This lack of exact and complete correspondence is not unexpected, since the oxygen isotopic signal responds to global changes, while the IRD record is controlled by both hemispheric and local or regional influences. Jansen et al. (this volume) identify the effect of regional influences on other paleoclimatic proxy records from these sites, including the oxygen isotopic and carbonate abundance records. Kellogg $(1977,1980)$ also recognized the importance of local effects, especially during "glacial" and "transitional" climatic modes. 


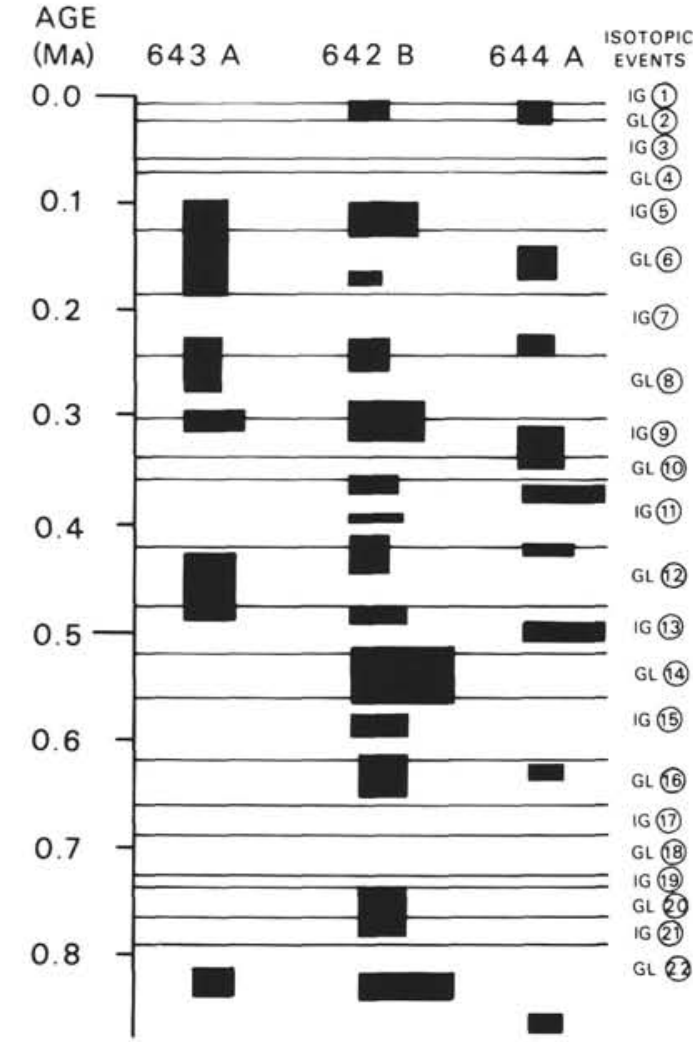

Figure 6. Generalized records of IRD abundance at ODP Holes 642B, $643 \mathrm{~A}$, and $644 \mathrm{~A}$, with global oxygen isotope record of Imbrie et al. (1984) for preliminary comparison. Periods of sustained high IRD abundance are indicated by solid boxes; box width indicates the average IRD abundance for that peak. Increased IRD abundances generally occur during glacial stages or glacial-to-interglacial transitions. Difficulty of correlating IRD peaks between cores apparently reflects source area and oceanic circulation effects.

\section{CONCLUSIONS}

Examination of the IRD records for the past 1.2 m.y. at ODP Holes $643 \mathrm{~A}$ and $644 \mathrm{~A}$ and the past 3.9 m.y. at Hole 642B has demonstrated the following:

1. Limited data indicate that minor IRD deposition in the Norwegian Sea began at approximately 2.9 Ma. Major input of IRD began at approximately $2.45 \mathrm{Ma}$. This transitional increase in IRD importance may explain the inconsistent ages determined for the onset of ice-rafting by using more southerly data sets.

2. Large peaks in IRD abundance during the Pleistocene first appear at $0.84 \mathrm{Ma}$ at Hole 642B, but do not occur at Hole $644 \mathrm{~A}$ until approximately $0.56 \mathrm{Ma}$. The diachronous nature of this increase may reflect both the gradual southward expansion of continental glaciation and the influence of northerly currents on landward locations.

3. IRD is slightly more abundant at Hole 642B than at Hole $644 \mathrm{~A}$ in sediments younger than $1.0 \mathrm{Ma}$. This seaward increase in IRD may reflect dilution by more rapid sedimentation at Site 644. The seaward increase may also reflect the importance of different sources for the IRD at these two sites and the effect of northerly flow near the continent.

4. A preliminary comparison indicates that major peaks in generalized IRD records from the Norwegian Sea predominantly occur during glacial stages or at glacial-interglacial tran- sitions, as defined by the globally averaged oxygen isotope record of Imbrie et al. (1984). This general correlation indicates the influence of hemispheric/global climate on IRD production, although local/regional controls (IRD sources and circulation patterns) are also important.

\section{ACKNOWLEDGMENTS}

The assistance of the captain, crew, and technical staff of JOIDES Resolution on Leg 104 in obtaining these samples is gratefully acknowledged. David Hawkins, Mark Nelson, Jeffrey Bauer, Britt Leatham, Kenneth Coats, Paul Spahr, and Richard Jacko assisted with various portions of the laboratory analyses. Kenneth Coats provided patient tutorials on data manipulation and graph production by microcomputer. Three anonymous reviewers provided comments that substantially improved this discussion. This work was supported by a grant from the U.S. Science Advisory Committee to ODP.

\section{REFERENCES}

Backman, J., 1979. Pliocene biostratigraphy of DSDP Sites 111 and 116 from the North Atlantic Ocean and the age of northern hemisphere glaciation. Acta Univ. Stockh. Contrib. Geol., 32: 115-137.

Berggren, W. A., 1972. Late Pliocene-Pleistocene glaciation. In Laughton, A. S., Berggren, W. A., et al., Init. Repts. DSDP, 12: Washington (U.S. Govt. Printing Office), 953-963.

Bramlette, M. N., and Bradley, W. H., 1940. Geology and biology of North Atlantic deep-sea cores between Newfoundland and Ireland, Part I: Lithology and geologic interpretations. U.S. Geol. Surv. Prof. Pap. 196-A: Washington (U.S. Govt. Printing Office), 1-34.

Carney, T. R., 1986. Late Pliocene and Pleistocene paleoclimatic fluctuations determined by mass accumulation rate of ice-rafted detritus from Deep Sea Drilling Project Site 580, northwest Pacific [M. Sc. Thesis]. Ohio State University, Columbus.

Conolly, J. R., and Ewing, M., 1965. Pleistocene glacial marine zones in North Atlantic deep-sea sediments. Nature, 208: 135-138.

Eldholm, O., Thiede, J., Taylor, E., et al., 1987. Proc. ODP, Init. Repts., 104: College Station, TX (Ocean Drilling Program).

Herman, Y., and Hopkins, D., 1980. Arctic oceanic climate in late Cenozoic time. Science, 209: 557-562.

Imbrie, J., Hays, J. D., Martinson, D. G., McIntyre, A., Mix, A. C., Morley, J. J., Pisias, N. G., Prell, W. G., and Shackleton, N. J., 1984. The orbital theory of Pleistocene climate: support from a revised chronology of the marine ${ }^{18} \mathrm{O}$ record. In Berger, A. L., et al. (Eds.), Milankovitch and climate: understanding the response to astronomical forcing: Boston (D. Reidel), 269-305.

Kellogg, T., 1975. Late Quaternary climatic changes in the Norwegian and Greenland Seas. In Weller, G., and Bowling, S. A. (Eds.), Climate of the Arctic: Fairbanks (The Geophysical Institute), 3-36.

Kellogg, T., 1976. Late Quaternary climatic changes: evidence from deep-sea cores of Norwegian and Greenland Seas. In Cline, R. M., and Hays, J. D. (Eds.), Investigation of Late Quaternary Paleoceanography and Paleoclimatology. Mem. Geol. Soc. Am., 145: 77-110.

Kellogg, T., 1977. Paleoclimatology and paleo-oceanography of the Norwegian and Greenland Seas: the last 450,000 years. Mar. Micropaleontology, 2: 235-249.

Kellogg, T., 1980. Paleoclimatology and paleo-oceanography of the Norwegian and Greenland Seas: glacial-interglacial contrasts. Boreas, 15: 115-137.

Krissek, L. A., Morley, J. J., and Lofland, D. K., 1985. The occurrence, abundance, and composition of ice-rafted detritus in sediments from Deep Sea Drilling Project Sites 579 and 580, northwest Pacific. In Heath, G. R., Burckle, L., et al., Init. Repts. DSDP, 86: Washington (U.S. Govt. Printing Office), 647-655.

Margolis, S. V., and Herman, Y., 1980. Northern Hemisphere sea-ice and glacial development in the late Cenozoic. Nature, 286: 145-149.

Morley, J. J., 1986. Comparison of the Pleistocene records of the radiolarian Cycladophora davisiana at high-latitude sites of the Deep Sea Drilling Project. In Ruddiman, W. F., Kidd, R. B., et al., Init. Repts. DSDP, 94, Pt. 2: Washington (U.S. Govt. Printing Office), 889-894.

Morley, J. J., Pisias, N. G., and Leinen, M., 1987. Late Pleistocene time series of atmospheric and oceanic variables recorded in sediments from the subarctic Pacific. Paleoceanography, 2: 49-62. 
Poore, R. Z., 1981. Temporal and spatial distribution of ice-rafted mineral grains in Pliocene sediments of the North Atlantic. In Warme, J. E., Douglas, R. G., and Winterer, E. L. (Eds.), The Deep Sea Drilling Project: A Decade of Progress, Soc. Econ. Paleontol. Mineral. Spec. Publ. 32, 505-515.

Raymo, M. E., and Ruddiman, W. F., 1987. Response of the North Atlantic Ocean to late Pliocene glaciation of the Northern Hemisphere. EOS: Trans. Am. Geophys. Union, 68: 332. (Abstract)

Raymo, M. E., Ruddiman, W. F., and Clement, B. M., 1986. PliocenePleistocene paleoceanography of the North Atlantic at Deep Sea Drilling Project Site 609. In Ruddiman, W. F., Kidd, R. B., et al., Init. Repts. DSDP, 94, Pt. 2: Washington (U.S. Govt. Printing Office), 895-901.

Roberts, D. G., Schnitker, D., et al., 1982. Leg 81 drills west margin, Rockall Plateau. Geotimes, 21: 21-23.

Ruddiman, W. F., 1977a. North Atlantic ice-rafting: a major climatic change at 75,000 years before the present. Science, 196: 1208-1211.

Ruddiman, W. F., 1977b. Late Quaternary deposition of ice-rafted sand in the subpolar North Atlantic (lat $40^{\circ}$ to $65^{\circ} \mathrm{N}$ ). Geol. Soc. Am. Bull., 88: 1813-1827.

Ruddiman, W. F., Backman, J., Baldauf, J., Hooper, P., Keigwin, L., Miller, K., Raymo, M., and Thomas, E., 1986. Leg 94 paleoenvironmental synthesis. In Ruddiman, W. F., Kidd, R. B., et al., Init. Repts. DSDP, 94, Pt. 2: Washington (U.S. Govt. Printing Office), 1207-1215.

Ruddiman, W. F., and Glover, L. K., 1972a. Ice-rafted volcanic ash: a tracer of North Atlantic paleocirculation. EOS: Trans. Am. Geophys. Union, 53: 423. (Abstract)

Ruddiman, W. F., and Glover, L. K., 1972b. Vertical mixing of icerafted volcanic ash in North Atlantic sediments. Geol. Soc. Am. Bull., 83: 2817-2836.
Ruddiman, W. F., and McIntyre, A., 1976. Northeast Atlantic paleoclimatic changes over the past 600,000 years. In Cline, R. M., and Hays, J. D. (Eds.), Investigations of Late Quaternary Paleoceanography and Paleoclimatology, Mem. Geol. Soc. Am., 145: 111-146.

Ruddiman, W. F., McIntyre, A., and Raymo, M., 1986. Paleoenvironmental results from North Atlantic Sites 607 and 609. In Ruddiman, W. F., Kidd, R. B., et al., Init. Repts. DSDP, 94, Pt. 2: Washington (U.S. Govt. Printing Office), 855-878.

Sancetta, C., and Silvestri, S., 1986. Pliocene-Pleistocene evolution of the North Pacific ocean-atmosphere system, interpreted from fossil diatoms. Paleoceanography, 1: 163-180.

Schnitker, D., 1982. Regular fluctuations of northeast Atlantic environments- Miocene to Recent. EOS: Trans. Am. Geophys. Union, 63: 984. (Abstract)

Shackleton, N. J., Backman, J., Zimmerman, H., Kent, D. V., Hall, M. A., Roberts, D. G., Schnitker, D., Baldauf, J. G., Desprairies, A., Homrighausen, R., Huddlestun, P., Keene, J. B., Kaltenback, A. J., Krumsiek, K.A.O., Morton, A. C., Murray, J. W., and Westberg-Smith, J., 1984. Oxygen isotope calibration of the onset of icerafting and history of glaciation in the North Atlantic region. $\mathrm{Na}$ ture, 307: 620-623.

Shor, A. N., and Poore, R. Z., 1978. Bottom currents and ice-rafting in the North Atlantic: interpretation of Neogene depositional environments of Leg 49 cores. In Luyendyk, B. P., Cann, J. R., et al., Init. Repts. DSDP, 49: Washington (U.S. Govt. Printing Office), 859872.

Talwani, M., Udintsev, G., et al., 1976. Init. Repts. DSDP, 38: Washington (U.S. Govt. Printing Office).

Date of initial receipt: 14 July 1987

Date of acceptance: 14 April 1988

Ms 104B-114 
APPENDIX A

Abundances (weight \%) of coarse-sand IRD in samples from ODP Hole 642B, with ages interpolated using constant sedimentation rates between paleomagnetic datums.

\begin{tabular}{|c|c|c|c|c|c|c|}
\hline Hole & Core & $\begin{array}{c}\text { Sample } \\
\text { top } \\
(\mathrm{cm})\end{array}$ & $\begin{array}{c}\text { Sample } \\
\text { base } \\
(\mathrm{cm})\end{array}$ & $\begin{array}{l}\text { Depth } \\
\text { (mbsf) }\end{array}$ & $\begin{array}{l}\text { IRD } \\
\text { wt } \%\end{array}$ & $\begin{array}{l}\text { Age } \\
\text { (Ma) }\end{array}$ \\
\hline $642 \mathrm{~B}$ & $1 \mathrm{H}-01$ & 10 & 12 & 0.11 & 0.31 & 0.002 \\
\hline $642 B$ & $1 \mathrm{H}-01$ & 33 & 35 & 0.34 & 2.04 & 0.007 \\
\hline $642 \mathrm{~B}$ & $1 \mathrm{H}-01$ & 59 & 61 & 0.60 & 1.86 & 0.012 \\
\hline $642 B$ & $1 \mathrm{H}-01$ & 85 & 87 & 0.86 & 1.59 & 0.017 \\
\hline $642 B$ & $1 \mathrm{H}-01$ & 112 & 114 & 1.13 & 1.62 & 0.022 \\
\hline $642 B$ & $1 \mathrm{H}-01$ & 135 & 137 & 1.36 & 0.33 & 0.027 \\
\hline $642 B$ & $1 \mathrm{H}-02$ & 10 & 12 & 1.61 & 0.49 & 0.032 \\
\hline $642 B$ & $1 \mathrm{H}-02$ & 33 & 35 & 1.84 & 0.41 & 0.036 \\
\hline $642 B$ & $1 \mathrm{H}-02$ & 59 & 61 & 2.10 & 0.29 & 0.041 \\
\hline $642 B$ & $1 \mathrm{H}-02$ & 85 & 87 & 2.36 & 0.62 & 0.046 \\
\hline $642 B$ & $1 \mathrm{H}-02$ & 104 & 106 & 2.55 & 0.51 & 0.050 \\
\hline $642 B$ & $1 \mathrm{H}-02$ & 128 & 130 & 2.79 & 0.66 & 0.055 \\
\hline $642 B$ & $1 \mathrm{H}-03$ & 33 & 35 & 3.36 & 0.93 & 0.066 \\
\hline $642 B$ & $1 \mathrm{H}-03$ & 59 & 61 & 3.60 & 0.45 & 0.071 \\
\hline $642 B$ & $1 \mathrm{H}-03$ & 85 & 87 & 3.86 & 1.05 & 0.076 \\
\hline $642 B$ & $1 \mathrm{H}-03$ & 112 & 114 & 4.13 & 0.31 & 0.081 \\
\hline $642 B$ & $1 \mathrm{H}-03$ & 135 & 137 & 4.36 & 0.61 & 0.086 \\
\hline $642 B$ & $2 \mathrm{H}-01$ & 57 & 59 & 5.38 & 1.32 & 0.106 \\
\hline $642 B$ & $2 \mathrm{H}-01$ & 87 & 89 & 5.68 & 1.18 & 0.112 \\
\hline $642 B$ & $2 \mathrm{H}-01$ & 106 & 108 & 5.87 & 2.47 & 0.116 \\
\hline $642 B$ & $2 \mathrm{H}-01$ & 127 & 129 & 6.08 & 3.37 & 0.120 \\
\hline $642 B$ & $2 \mathrm{H}-02$ & 30 & 32 & 6.61 & 3.23 & 0.130 \\
\hline $642 B$ & $2 \mathrm{H}-02$ & 59 & 61 & 6.90 & 0.97 & 0.136 \\
\hline $642 B$ & $2 \mathrm{H}-02$ & 83 & 85 & 7.14 & 0.15 & 0.141 \\
\hline $642 B$ & $2 \mathrm{H}-02$ & 87 & 89 & 7.18 & 0.78 & 0.141 \\
\hline $642 B$ & $2 \mathrm{H}-02$ & 106 & 108 & 7.37 & 0.86 & 0.145 \\
\hline $642 B$ & $2 \mathrm{H}-02$ & 127 & 129 & 7.58 & 0.63 & 0.149 \\
\hline $642 B$ & $2 \mathrm{H}-03$ & 4 & 6 & 7.85 & 1.56 & 0.155 \\
\hline $642 B$ & $2 \mathrm{H}-03$ & 30 & 32 & 8.11 & 0.81 & 0.160 \\
\hline $642 B$ & $2 \mathrm{H}-03$ & 59 & 61 & 8.40 & 0.57 & 0.165 \\
\hline $642 B$ & $2 \mathrm{H}-03$ & 87 & 89 & 8.68 & 1.27 & 0.171 \\
\hline $642 B$ & $2 \mathrm{H}-03$ & 106 & 108 & 8.87 & 1.58 & 0.175 \\
\hline $642 B$ & $2 \mathrm{H}-03$ & 127 & 129 & 9.08 & 0.41 & 0.179 \\
\hline $642 B$ & $2 \mathrm{H}-04$ & 30 & 32 & 9.61 & 1.31 & 0.189 \\
\hline $642 B$ & $2 \mathrm{H}-04$ & 59 & 61 & 9.90 & 0.89 & 0.195 \\
\hline $642 B$ & $2 \mathrm{H}-04$ & 87 & 89 & 10.18 & 0.86 & 0.200 \\
\hline $642 B$ & $2 \mathrm{H}-04$ & 106 & 108 & 10.37 & 1.38 & 0.204 \\
\hline $642 B$ & $2 \mathrm{H}-04$ & 127 & 129 & 10.58 & 0.94 & 0.208 \\
\hline $642 B$ & $2 \mathrm{H}-05$ & 3 & 5 & 10.84 & 0.92 & 0.213 \\
\hline $642 B$ & $2 \mathrm{H}-05$ & 30 & 32 & 11.11 & 0.53 & 0.219 \\
\hline $642 B$ & $2 \mathrm{H}-05$ & 59 & 61 & 11.40 & 0.66 & 0.224 \\
\hline $642 B$ & $2 \mathrm{H}-05$ & 87 & 89 & 11.68 & 1.24 & 0.230 \\
\hline $642 B$ & $2 \mathrm{H}-05$ & 106 & 108 & 11.87 & 2.84 & 0.234 \\
\hline $642 B$ & $2 \mathrm{H}-05$ & 127 & 129 & 12.08 & 0.86 & 0.238 \\
\hline $642 B$ & $2 \mathrm{H}-6$ & 7 & 9 & 12.38 & 0.96 & 0.244 \\
\hline $642 B$ & $2 \mathrm{H}-06$ & 29 & 31 & 12.60 & 1.36 & 0.248 \\
\hline $642 B$ & $2 \mathrm{H}-06$ & 58 & 60 & 12.89 & 1.48 & 0.254 \\
\hline $642 \mathrm{~B}$ & $2 \mathrm{H}-06$ & 87 & 89 & 13.18 & 1.52 & 0.259 \\
\hline $642 B$ & $3 \mathrm{H}-01$ & 15 & 17 & 14.46 & 0.58 & 0.285 \\
\hline $642 \mathrm{~B}$ & $3 \mathrm{H}-01$ & 33 & 35 & 14.64 & 2.18 & 0.288 \\
\hline $642 B$ & $3 \mathrm{H}-01$ & 55 & 57 & 14.86 & 1.42 & 0.293 \\
\hline $642 B$ & $3 \mathrm{H}-01$ & 84 & 86 & 15.15 & 1.42 & 0.298 \\
\hline $642 B$ & $3 \mathrm{H}-01$ & 114 & 116 & 15.45 & 4.99 & 0.304 \\
\hline $642 B$ & $3 \mathrm{H}-01$ & 138 & 140 & 15.69 & 0.51 & 0.309 \\
\hline $642 B$ & $3 \mathrm{H}-02$ & 16 & 18 & 15.97 & 4.75 & 0.314 \\
\hline $642 B$ & $3 \mathrm{H}-02$ & 33 & 35 & 16.14 & 2.88 & 0.318 \\
\hline $642 B$ & $3 \mathrm{H}-02$ & 55 & 57 & 16.36 & 0.71 & 0.322 \\
\hline $642 B$ & $3 \mathrm{H}-02$ & 77 & 79 & 16.58 & 2.61 & 0.326 \\
\hline $642 B$ & $3 \mathrm{H}-02$ & 138 & 140 & 17.19 & 0.27 & 0.338 \\
\hline $642 B$ & $3 \mathrm{H}-03$ & 30 & 32 & 17.61 & 0.26 & 0.347 \\
\hline $642 B$ & $3 \mathrm{H}-03$ & 55 & 57 & 17.86 & 0.43 & 0.352 \\
\hline $642 B$ & $3 \mathrm{H}-03$ & 77 & 79 & 18.08 & 0.15 & 0.356 \\
\hline $642 B$ & $3 \mathrm{H}-03$ & 104 & 106 & 18.35 & 1.69 & 0.361 \\
\hline $642 \mathrm{~B}$ & $3 \mathrm{H}-03$ & 114 & 116 & 18.45 & 2.08 & 0.363 \\
\hline $642 B$ & $3 \mathrm{H}-04$ & 15 & 17 & 18.96 & 1.11 & 0.373 \\
\hline $642 B$ & $3 \mathrm{H}-04$ & 33 & 35 & 19.14 & 0.25 & 0.377 \\
\hline $642 B$ & $3 \mathrm{H}-04$ & 55 & 57 & 19.36 & 0.32 & 0.381 \\
\hline $642 \mathrm{~B}$ & $3 \mathrm{H}-04$ & 77 & 79 & 19.58 & 0.28 & 0.385 \\
\hline $642 \mathrm{~B}$ & $3 \mathrm{H}-04$ & 103 & 105 & 19.84 & 0.35 & 0.391 \\
\hline $642 B$ & $3 \mathrm{H}-04$ & 128 & 130 & 20.09 & 1.05 & 0.395 \\
\hline $642 B$ & $3 \mathrm{H}-04$ & 150 & 152 & 20.31 & 2.31 & 0.400 \\
\hline
\end{tabular}

Appendix A (continued).

\begin{tabular}{|c|c|c|c|c|c|c|}
\hline Hole & Core & $\begin{array}{c}\text { Sample } \\
\text { top } \\
(\mathrm{cm})\end{array}$ & $\begin{array}{c}\text { Sample } \\
\text { base } \\
(\mathrm{cm})\end{array}$ & $\begin{array}{l}\text { Depth } \\
\text { (mbsf) }\end{array}$ & $\begin{array}{l}\text { IRD } \\
\text { wt } \%\end{array}$ & $\begin{array}{l}\text { Age } \\
\text { (Ma) }\end{array}$ \\
\hline 642B & $4 \mathrm{H}-01$ & 14 & 16 & 20.85 & 0.87 & 0.410 \\
\hline $642 B$ & $4 \mathrm{H}-01$ & 32 & 34 & 21.03 & 0.65 & 0.414 \\
\hline 642B & $4 \mathrm{H}-01$ & 54 & 56 & 21.25 & 1.21 & 0.481 \\
\hline $642 \mathrm{~B}$ & $4 \mathrm{H}-01$ & 83 & 85 & 21.54 & 1.01 & 0.424 \\
\hline $642 \mathrm{~B}$ & $4 \mathrm{H}-01$ & 104 & 106 & 21.75 & 0.72 & 0.428 \\
\hline 642B & $4 \mathrm{H}-01$ & 132 & 134 & 22.03 & 1.09 & 0.434 \\
\hline $642 \mathrm{~B}$ & $4 \mathrm{H}-02$ & 12 & 14 & 22.33 & 2.25 & 0.440 \\
\hline 642B & $4 \mathrm{H}-02$ & 14 & 16 & 22.35 & 0.84 & 0.440 \\
\hline $642 \mathrm{~B}$ & $4 \mathrm{H}-02$ & 32 & 34 & 22.53 & 0.99 & 0.444 \\
\hline $642 \mathrm{~B}$ & $4 \mathrm{H}-02$ & 54 & 56 & 22.75 & 1.27 & 0.448 \\
\hline $642 \mathrm{~B}$ & $4 \mathrm{H}-02$ & 104 & 106 & 23.25 & 0.42 & 0.458 \\
\hline 642B & $4 \mathrm{H}-03$ & 14 & 16 & 23.85 & 0.31 & 0.469 \\
\hline $642 B$ & $4 \mathrm{H}-03$ & 32 & 34 & 24.03 & 0.17 & 0.473 \\
\hline 642B & $4 \mathrm{H}-03$ & 83 & 85 & 24.54 & 2.61 & 0.483 \\
\hline 642B & $4 \mathrm{H}-03$ & 104 & 106 & 24.75 & 2.01 & 0.487 \\
\hline 642B & $4 \mathrm{H}-03$ & 132 & 134 & 25.03 & 1.92 & 0.493 \\
\hline 642B & $4 \mathrm{H}-04$ & 14 & 15 & 25.35 & 0.36 & 0.499 \\
\hline $642 B$ & $4 \mathrm{H}-04$ & 32 & 34 & 25.53 & 1.65 & 0.503 \\
\hline $642 B$ & $4 \mathrm{H}-04$ & 54 & 56 & 25.75 & 0.45 & 0.507 \\
\hline $642 \mathrm{~B}$ & $4 \mathrm{H}-04$ & 83 & 85 & 26.04 & 0.14 & 0.513 \\
\hline $642 B$ & $4 \mathrm{H}-04$ & 104 & 106 & 26.25 & 0.61 & 0.517 \\
\hline 642B & $4 \mathrm{H}-04$ & 121 & 123 & 26.42 & 1.65 & 0.520 \\
\hline $642 \mathrm{~B}$ & $4 \mathrm{H}-05$ & 14 & 16 & 26.85 & 4.75 & 0.529 \\
\hline $642 \mathrm{~B}$ & $4 \mathrm{H}-05$ & 32 & 34 & 27.03 & 6.93 & 0.532 \\
\hline $642 B$ & $4 \mathrm{H}-05$ & 54 & 56 & 27.25 & 6.41 & 0.536 \\
\hline $642 \mathrm{~B}$ & $4 \mathrm{H}-05$ & 83 & 85 & 27.54 & 4.88 & 0.542 \\
\hline $642 \mathrm{~B}$ & $4 \mathrm{H}-05$ & 104 & 106 & 27.75 & 0.99 & 0.546 \\
\hline 642B & $4 \mathrm{H}-05$ & 132 & 134 & 28.03 & 1.06 & 0.552 \\
\hline 642B & $4 \mathrm{H}-06$ & 14 & 16 & 28.35 & 2.76 & 0.558 \\
\hline 642B & $4 \mathrm{H}-06$ & 32 & 34 & 28.53 & 1.11 & 0.562 \\
\hline 642B & $4 \mathrm{H}-06$ & 54 & 56 & 28.75 & 2.77 & 0.566 \\
\hline $642 \mathrm{~B}$ & $4 \mathrm{H}-06$ & 83 & 85 & 29.04 & 0.48 & 0.572 \\
\hline $642 \mathrm{~B}$ & $4 \mathrm{H}-06$ & 104 & 106 & 29.74 & 0.83 & 0.585 \\
\hline $642 \mathrm{~B}$ & $4 \mathrm{H}-06$ & 132 & 134 & 29.53 & 2.28 & 0.581 \\
\hline $642 \mathrm{~B}$ & $5 \mathrm{H}-01$ & 17 & 19 & 29.58 & 1.23 & 0.582 \\
\hline $642 \mathrm{~B}$ & $5 \mathrm{H}-01$ & 39 & 41 & 29.80 & 2.05 & 0.587 \\
\hline $642 B$ & $5 \mathrm{H}-01$ & 53 & 55 & 29.94 & 2.34 & 0.589 \\
\hline $642 B$ & $5 \mathrm{H}-01$ & 85 & 87 & 30.26 & 1.96 & 0.596 \\
\hline $642 \mathrm{~B}$ & $5 \mathrm{H}-01$ & 105 & 107 & 30.46 & 0.65 & 0.600 \\
\hline 642B & $5 \mathrm{H}-01$ & 128 & 130 & 30.69 & 0.57 & 0.604 \\
\hline $642 \mathrm{~B}$ & $5 \mathrm{H}-02$ & 17 & 19 & 31.08 & 0.61 & 0.612 \\
\hline $642 \mathrm{~B}$ & $5 \mathrm{H}-02$ & 39 & 41 & 31.31 & 0.41 & 0.616 \\
\hline $642 B$ & $5 \mathrm{H}-02$ & 53 & 55 & 31.44 & 1.05 & 0.619 \\
\hline 642B & $5 \mathrm{H}-02$ & 85 & 87 & 31.76 & 2.02 & 0.625 \\
\hline $642 B$ & $5 \mathrm{H}-02$ & 105 & 107 & 31.96 & 0.78 & 0.629 \\
\hline 642B & $5 \mathrm{H}-03$ & 17 & 19 & 32.58 & 2.73 & 0.641 \\
\hline $642 B$ & $5 \mathrm{H}-03$ & 39 & 41 & 32.80 & 2.93 & 0.646 \\
\hline $642 \mathrm{~B}$ & $5 \mathrm{H}-03$ & 53 & 55 & 32.94 & 1.07 & 0.648 \\
\hline 642B & $5 \mathrm{H}-03$ & 85 & 87 & 33.26 & 2.04 & 0.655 \\
\hline 642B & $5 \mathrm{H}-03$ & 105 & 107 & 33.46 & 0.56 & 0.659 \\
\hline 642B & $5 \mathrm{H}-03$ & 128 & 130 & 33.69 & 1.18 & 0.663 \\
\hline 642B & $5 \mathrm{H}-04$ & 17 & 19 & 34.08 & 0.27 & 0.671 \\
\hline $642 \mathrm{~B}$ & $5 \mathrm{H}-04$ & 39 & 41 & 34.30 & 2.21 & 0.675 \\
\hline 642B & $5 \mathrm{H}-04$ & 53 & 55 & 34.44 & 0.33 & 0.678 \\
\hline $642 \mathrm{~B}$ & $5 \mathrm{H}-04$ & 85 & 87 & 34.76 & 0.67 & 0.684 \\
\hline $642 \mathrm{~B}$ & $5 \mathrm{H}-04$ & 105 & 107 & 34.96 & 0.55 & 0.688 \\
\hline $642 B$ & $5 \mathrm{H}-05$ & 17 & 19 & 35.58 & 1.61 & 0.700 \\
\hline $642 \mathrm{~B}$ & $5 \mathrm{H}-05$ & 39 & 41 & 35.80 & 0.43 & 0.705 \\
\hline $642 \mathrm{~B}$ & $5 \mathrm{H}-05$ & 53 & 55 & 35.94 & 1.01 & 0.707 \\
\hline $642 \mathrm{~B}$ & $5 \mathrm{H}-05$ & 85 & 87 & 36.26 & 0.86 & 0.714 \\
\hline $642 \mathrm{~B}$ & $5 \mathrm{H}-05$ & 105 & 107 & 36.46 & 0.45 & 0.718 \\
\hline $642 B$ & $5 \mathrm{H}-05$ & 128 & 130 & 36.69 & 0.55 & 0.722 \\
\hline $642 \mathrm{~B}$ & $5 \mathrm{H}-06$ & 17 & 19 & 37.08 & 0.47 & 0.730 \\
\hline $642 \mathrm{~B}$ & $5 \mathrm{H}-06$ & 39 & 41 & 37.30 & 0.18 & 0.737 \\
\hline $642 \mathrm{~B}$ & $5 \mathrm{H}-06$ & 53 & 55 & 37.44 & 0.95 & 0.742 \\
\hline $642 \mathrm{~B}$ & $5 \mathrm{H}-06$ & 85 & 87 & 37.76 & 0.91 & 0.754 \\
\hline 642B & $5 \mathrm{H}-06$ & 105 & 107 & 37.96 & 1.04 & 0.762 \\
\hline $642 \mathrm{~B}$ & $5 \mathrm{H}-06$ & 128 & 130 & 38.19 & 1.59 & 0.770 \\
\hline $642 \mathrm{~B}$ & $5 \mathrm{H}-07$ & 14 & 16 & 38.55 & 4.31 & 0.784 \\
\hline $642 B$ & $5 \mathrm{H}-07$ & 39 & 41 & 38.80 & 0.09 & 0.793 \\
\hline 642B & $5 \mathrm{H}-07$ & 53 & 55 & 38.94 & 0.09 & 0.798 \\
\hline
\end{tabular}


Appendix A (continued).

\begin{tabular}{|c|c|c|c|c|c|c|}
\hline Hole & Core & $\begin{array}{c}\text { Sample } \\
\text { top } \\
(\mathrm{cm})\end{array}$ & $\begin{array}{c}\text { Sample } \\
\text { base } \\
(\mathrm{cm})\end{array}$ & $\begin{array}{l}\text { Depth } \\
\text { (mbsf) }\end{array}$ & $\begin{array}{l}\text { IRD } \\
\text { wt } \%\end{array}$ & $\begin{array}{l}\text { Age } \\
\text { (Ma) }\end{array}$ \\
\hline $642 B$ & $6 \mathrm{H}-01$ & 17 & 19 & 39.08 & 1.91 & 0.803 \\
\hline $642 B$ & $5 \mathrm{H}-07$ & 85 & 87 & 39.26 & 0.21 & 0.810 \\
\hline $642 B$ & $6 \mathrm{H}-01$ & 39 & 41 & 39.30 & 0.19 & 0.811 \\
\hline $642 B$ & $6 \mathrm{H}-01$ & 70 & 72 & 39.61 & 7.33 & 0.823 \\
\hline $642 B$ & $6 \mathrm{H}-01$ & 87 & 89 & 39.78 & 1.19 & 0.829 \\
\hline $642 \mathrm{~B}$ & $6 \mathrm{H}-01$ & 115 & 117 & 40.06 & 1.04 & 0.840 \\
\hline $642 B$ & $6 \mathrm{H}-01$ & 144 & 146 & 40.35 & 0.38 & 0.850 \\
\hline $642 B$ & $6 \mathrm{H}-02$ & 17 & 19 & 40.58 & 1.28 & 0.859 \\
\hline $642 B$ & $6 \mathrm{H}-02$ & 39 & 41 & 40.80 & 0.29 & 0.867 \\
\hline $642 B$ & $6 \mathrm{H}-02$ & 70 & 72 & 41.11 & 0.87 & 0.879 \\
\hline $642 B$ & $6 \mathrm{H}-02$ & 87 & 89 & 41.28 & 1.74 & 0.885 \\
\hline $642 B$ & $6 \mathrm{H}-02$ & 115 & 117 & 41.56 & 1.46 & 0.895 \\
\hline $642 B$ & $6 \mathrm{H}-02$ & 144 & 146 & 41.85 & 1.18 & 0.906 \\
\hline $642 B$ & $6 \mathrm{H}-03$ & 17 & 19 & 42.08 & 1.12 & 0.912 \\
\hline $642 B$ & $6 \mathrm{H}-03$ & 39 & 41 & 42.30 & 1.42 & 0.917 \\
\hline $642 B$ & $6 \mathrm{H}-03$ & 68 & 70 & 42.59 & 0.51 & 0.922 \\
\hline $642 B$ & $6 \mathrm{H}-03$ & 87 & 89 & 42.78 & 1.77 & 0.926 \\
\hline $642 B$ & $6 \mathrm{H}-03$ & 115 & 117 & 43.06 & 0.41 & 0.931 \\
\hline $642 B$ & $6 \mathrm{H}-03$ & 144 & 146 & 43.35 & 0.65 & 0.937 \\
\hline $642 B$ & $6 \mathrm{H}-04$ & 17 & 19 & 43.58 & 0.89 & 0.942 \\
\hline $642 B$ & $6 \mathrm{H}-04$ & 39 & 41 & 43.80 & 1.15 & 0.946 \\
\hline $642 B$ & $6 \mathrm{H}-04$ & 70 & 72 & 44.11 & 1.33 & 0.952 \\
\hline $642 B$ & $6 \mathrm{H}-04$ & 87 & 89 & 44.28 & 0.12 & 0.955 \\
\hline $642 B$ & $6 \mathrm{H}-04$ & 115 & 117 & 44.56 & 1.44 & 0.961 \\
\hline $642 B$ & $6 \mathrm{H}-05$ & 17 & 19 & 45.08 & 2.71 & 0.971 \\
\hline $642 B$ & $6 \mathrm{H}-05$ & 39 & 41 & 45.30 & 1.06 & 0.975 \\
\hline $642 B$ & $6 \mathrm{H}-05$ & 70 & 72 & 45.61 & 1.02 & 0.985 \\
\hline $642 B$ & $6 \mathrm{H}-05$ & 87 & 89 & 45.78 & 2.13 & 1.001 \\
\hline $642 B$ & $6 \mathrm{H}-05$ & 115 & 117 & 46.06 & 1.37 & 1.027 \\
\hline $642 B$ & $6 \mathrm{H}-05$ & 144 & 146 & 46.35 & 0.25 & 1.055 \\
\hline $642 B$ & $6 \mathrm{H}-06$ & 17 & 19 & 46.58 & 0.37 & 1.076 \\
\hline $642 B$ & $6 \mathrm{H}-06$ & 39 & 41 & 46.80 & 1.81 & 1.097 \\
\hline $642 B$ & $7 \mathrm{H}-01$ & 29 & 31 & 47.70 & 2.48 & 1.182 \\
\hline $642 B$ & $7 \mathrm{H}-01$ & 58 & 60 & 47.99 & 0.71 & 1.209 \\
\hline $642 B$ & $7 \mathrm{H}-01$ & 81 & 83 & 48.22 & 1.21 & 1.231 \\
\hline $642 B$ & 7H-01 & 105 & 107 & 48.46 & 0.47 & 1.254 \\
\hline $642 B$ & $7 \mathrm{H}-01$ & 122 & 124 & 48.63 & 0.18 & 1.270 \\
\hline $642 B$ & $7 \mathrm{H}-01$ & 142 & 144 & 48.83 & 1.96 & 1.288 \\
\hline $642 B$ & $7 \mathrm{H}-02$ & 29 & 31 & 49.20 & 2.18 & 1.323 \\
\hline $642 B$ & $7 \mathrm{H}-02$ & 58 & 60 & 49.49 & 0.93 & 1.351 \\
\hline $642 B$ & $7 \mathrm{H}-02$ & 81 & 83 & 49.72 & 0.89 & 1.372 \\
\hline $642 B$ & $7 \mathrm{H}-02$ & 105 & 107 & 49.96 & 0.71 & 1.395 \\
\hline $642 B$ & $7 \mathrm{H}-02$ & 122 & 124 & 50.13 & 0.36 & 1.411 \\
\hline $642 B$ & $7 \mathrm{H}-02$ & 142 & 144 & 50.33 & 0.93 & 1.430 \\
\hline $642 B$ & $7 \mathrm{H}-03$ & 29 & 31 & 50.70 & 1.86 & 1.465 \\
\hline $642 B$ & $7 \mathrm{H}-03$ & 58 & 60 & 50.99 & 0.72 & 1.492 \\
\hline $642 B$ & 7H-03 & 81 & 83 & 51.22 & 0.06 & 1.514 \\
\hline $642 B$ & $7 \mathrm{H}-03$ & 104 & 106 & 51.45 & 0.21 & 1.536 \\
\hline $642 B$ & $7 \mathrm{H}-03$ & 105 & 107 & 51.46 & 1.51 & 1.537 \\
\hline $642 B$ & $7 \mathrm{H}-03$ & 122 & 124 & 51.63 & 0.64 & 1.553 \\
\hline $642 B$ & $7 \mathrm{H}-03$ & 142 & 144 & 51.83 & 1.02 & 1.572 \\
\hline $642 B$ & $7 \mathrm{H}-04$ & 29 & 31 & 52.20 & 0.49 & 1.606 \\
\hline $642 B$ & $7 \mathrm{H}-04$ & 58 & 60 & 52.49 & 1.46 & 1.634 \\
\hline $642 B$ & 7H-04 & 81 & 83 & 52.72 & 2.15 & 1.655 \\
\hline $642 B$ & 7H-04 & 102 & 104 & 52.93 & 3.41 & 1.677 \\
\hline $642 B$ & $7 \mathrm{H}-05$ & 29 & 31 & 53.70 & 0.85 & 1.747 \\
\hline $642 B$ & $7 \mathrm{H}-05$ & 58 & 60 & 53.99 & 0.12 & 1.774 \\
\hline $642 \mathrm{~B}$ & $7 \mathrm{H}-05$ & 81 & 83 & 54.22 & 0.82 & 1.795 \\
\hline $642 \mathrm{~B}$ & 7H-05 & 105 & 107 & 54.46 & 0.12 & 1.817 \\
\hline $642 B$ & $7 \mathrm{H}-05$ & 118 & 120 & 54.59 & 0.65 & 1.829 \\
\hline $642 B$ & $7 \mathrm{H}-05$ & 142 & 144 & 54.83 & 0.96 & 1.851 \\
\hline $642 B$ & 7H-06 & 29 & 31 & 55.20 & 3.25 & 1.883 \\
\hline $642 B$ & $7 \mathrm{H}-06$ & 54 & 56 & 55.45 & 0.91 & 1.899 \\
\hline $642 B$ & $7 \mathrm{H}-06$ & 81 & 83 & 55.72 & 0.22 & 1.915 \\
\hline $642 B$ & $7 \mathrm{H}-06$ & 105 & 107 & 55.96 & 2.54 & 1.930 \\
\hline $642 B$ & $7 \mathrm{H}-06$ & 118 & 120 & 56.09 & 1.07 & 1.938 \\
\hline $642 B$ & $7 \mathrm{H}-06$ & 142 & 144 & 56.33 & 1.12 & 1.953 \\
\hline $642 B$ & $7 \mathrm{H}-07$ & 29 & 31 & 56.70 & 1.25 & 1.976 \\
\hline $642 B$ & $7 \mathrm{H}-07$ & 54 & 56 & 56.95 & 0.56 & 1.992 \\
\hline $642 B$ & $8 \mathrm{H}-01$ & 12 & 14 & 57.03 & 1.66 & 1.997 \\
\hline $642 B$ & $8 \mathrm{H}-01$ & 33 & 35 & 57.24 & 0.35 & 2.010 \\
\hline $642 B$ & $8 \mathrm{H}-01$ & 52 & 54 & 57.43 & 0.71 & 2.022 \\
\hline $642 B$ & $8 \mathrm{H}-01$ & 78 & 80 & 57.69 & 0.91 & 2.038 \\
\hline $642 B$ & $8 \mathrm{H}-01$ & 105 & 107 & 57.96 & 0.01 & 2.055 \\
\hline $642 \mathrm{~B}$ & $8 \mathrm{H}-01$ & 135 & 137 & 58.26 & 0.00 & 2.073 \\
\hline $642 B$ & $8 \mathrm{H}-02$ & 12 & 14 & 58.53 & 0.18 & 2.090 \\
\hline $642 B$ & $8 \mathrm{H}-02$ & 33 & 35 & 58.74 & 0.34 & 2.103 \\
\hline
\end{tabular}

Appendix A (continued).

\begin{tabular}{|c|c|c|c|c|c|c|}
\hline Hole & Core & $\begin{array}{c}\text { Sample } \\
\text { top } \\
(\mathrm{cm})\end{array}$ & $\begin{array}{c}\text { Sample } \\
\text { base } \\
(\mathrm{cm})\end{array}$ & $\begin{array}{l}\text { Depth } \\
\text { (mbsf) }\end{array}$ & $\begin{array}{l}\text { IRD } \\
\text { wt \% }\end{array}$ & $\begin{array}{l}\text { Age } \\
\text { (Ma) }\end{array}$ \\
\hline $642 B$ & $8 \mathrm{H}-02$ & 58 & 60 & 58.99 & 0.00 & 2.119 \\
\hline $642 B$ & $8 \mathrm{H}-02$ & 78 & 80 & 59.19 & 0.00 & 2.131 \\
\hline $642 \mathrm{~B}$ & $8 \mathrm{H}-02$ & 105 & 107 & 59.46 & 0.00 & 2.148 \\
\hline $642 B$ & $8 \mathrm{H}-02$ & 135 & 137 & 59.76 & 0.71 & 2.166 \\
\hline 642B & $8 \mathrm{H}-03$ & 12 & 14 & 60.03 & 1.02 & 2.183 \\
\hline $642 B$ & $8 \mathrm{H}-03$ & 33 & 35 & 60.24 & 0.53 & 2.196 \\
\hline 642B & $8 \mathrm{H}-03$ & 58 & 60 & 60.49 & 0.12 & 2.212 \\
\hline $642 B$ & $8 \mathrm{H}-03$ & 78 & 80 & 60.69 & 0.76 & 2.224 \\
\hline 642B & $8 \mathrm{H}-03$ & 105 & 107 & 60.96 & 0.26 & 2.241 \\
\hline $642 B$ & $8 \mathrm{H}-03$ & 135 & 137 & 61.26 & 0.43 & 2.260 \\
\hline $642 \mathrm{~B}$ & $8 \mathrm{H}-04$ & 12 & 14 & 61.53 & 0.13 & 2.276 \\
\hline $642 B$ & $8 \mathrm{H}-04$ & 33 & 35 & 61.74 & 0.06 & 2.289 \\
\hline 642B & $8 \mathrm{H}-04$ & 58 & 60 & 61.99 & 0.01 & 2.305 \\
\hline $642 B$ & $8 \mathrm{H}-04$ & 78 & 80 & 62.19 & 0.62 & 2.317 \\
\hline $642 B$ & $8 \mathrm{H}-04$ & 105 & 107 & 62.46 & 2.96 & 2.334 \\
\hline $642 B$ & $8 \mathrm{H}-04$ & 135 & 137 & 62.76 & 1.14 & 2.353 \\
\hline $642 \mathrm{~B}$ & $8 \mathrm{H}-05$ & 12 & 14 & 63.03 & 1.11 & 2.369 \\
\hline $642 B$ & $8 \mathrm{H}-05$ & 33 & 35 & 63.24 & 2.45 & 2.382 \\
\hline $642 B$ & $8 \mathrm{H}-05$ & 58 & 60 & 63.49 & 0.17 & 2.398 \\
\hline $642 \mathrm{~B}$ & $8 \mathrm{H}-05$ & 78 & 80 & 63169 & 0.77 & 2.410 \\
\hline $642 B$ & $8 \mathrm{H}-05$ & 105 & 107 & 63.96 & 2.12 & 2.427 \\
\hline 642B & $8 \mathrm{H}-05$ & 135 & 137 & 64.26 & 1.43 & 2.446 \\
\hline $642 B$ & $8 \mathrm{H}-05$ & 12 & 14 & 64.53 & 0.11 & 2.463 \\
\hline $642 \mathrm{~B}$ & $8 \mathrm{H}-06$ & 33 & 35 & 64.74 & 0.13 & 2.488 \\
\hline $642 \mathrm{~B}$ & $8 \mathrm{H}-06$ & 58 & 60 & 64.99 & 1.77 & 2.537 \\
\hline 642B & $8 \mathrm{H}-06$ & 78 & 80 & 65.19 & 0.26 & 2.576 \\
\hline $642 B$ & $8 \mathrm{H}-06$ & 105 & 107 & 65.46 & 0.31 & 2.629 \\
\hline $642 \mathrm{~B}$ & $8 \mathrm{H}-06$ & 135 & 137 & 65.76 & 2.33 & 2.688 \\
\hline $642 \mathrm{~B}$ & $8 \mathrm{H}-07$ & 12 & 14 & 66.03 & 0.05 & 2.741 \\
\hline $642 B$ & $8 \mathrm{H}-07$ & 33 & 35 & 66.24 & 1.67 & 2.782 \\
\hline $642 \mathrm{~B}$ & $9 \mathrm{H}-01$ & 13 & 15 & 66.54 & 0.06 & 2.841 \\
\hline $642 B$ & $9 \mathrm{H}-01$ & 34 & 36 & 66.75 & 1.69 & 2.882 \\
\hline $642 B$ & $9 \mathrm{H}-01$ & 57 & 59 & 66.98 & 0.00 & 2.920 \\
\hline $642 B$ & $9 \mathrm{H}-01$ & 78 & 80 & 67.19 & 0.00 & 2.966 \\
\hline $642 \mathrm{~B}$ & $9 \mathrm{H}-01$ & 104 & 106 & 67.45 & 0.01 & 3.022 \\
\hline $642 B$ & $9 \mathrm{H}-01$ & 134 & 136 & 67.75 & 0.00 & 3.087 \\
\hline $642 \mathrm{~B}$ & $9 \mathrm{H}-02$ & 13 & 15 & 68.04 & 0.00 & 3.150 \\
\hline $642 B$ & $9 \mathrm{H}-02$ & 34 & 36 & 68.25 & 0.01 & 3.191 \\
\hline $642 \mathrm{~B}$ & $9 \mathrm{H}-02$ & 57 & 59 & 68.48 & 0.03 & 3.219 \\
\hline $642 \mathrm{~B}$ & $9 \mathrm{H}-02$ & 78 & 80 & 68.69 & 0.00 & 3.244 \\
\hline $642 \mathrm{~B}$ & $9 \mathrm{H}-02$ & 104 & 106 & 68.95 & 0.01 & 3.275 \\
\hline $642 \mathrm{~B}$ & $9 \mathrm{H}-02$ & 132 & 134 & 69.23 & 0.00 & 3.309 \\
\hline $642 \mathrm{~B}$ & $9 \mathrm{H}-03$ & 13 & 15 & 69.54 & 0.00 & 3.346 \\
\hline $642 \mathrm{~B}$ & $9 \mathrm{H}-03$ & 34 & 36 & 69.75 & 0.00 & 3.372 \\
\hline $642 \mathrm{~B}$ & $9 \mathrm{H}-03$ & 57 & 59 & 69.98 & 0.00 & 3.399 \\
\hline $642 B$ & $9 \mathrm{H}-03$ & 78 & 80 & 70.19 & 0.00 & 3.416 \\
\hline $642 B$ & $9 \mathrm{H}-04$ & 13 & 15 & 71.04 & 0.00 & 3.483 \\
\hline $642 \mathrm{~B}$ & $9 \mathrm{H}-04$ & 34 & 36 & 71.25 & 0.00 & 3.500 \\
\hline $642 \mathrm{~B}$ & $9 \mathrm{H}-04$ & 57 & 59 & 71.48 & 0.00 & 3.518 \\
\hline $642 \mathrm{~B}$ & $9 \mathrm{H}-04$ & 78 & 80 & 71.69 & 0.00 & 3.535 \\
\hline $642 B$ & $9 \mathrm{H}-04$ & 104 & 106 & 71.95 & 0.00 & 3.556 \\
\hline $642 \mathrm{~B}$ & $9 \mathrm{H}-04$ & 134 & 136 & 72.25 & 0.00 & 3.579 \\
\hline $642 \mathrm{~B}$ & $9 \mathrm{H}-05$ & 13 & 15 & 72.54 & 0.00 & 3.602 \\
\hline $642 B$ & $9 \mathrm{H}-05$ & 34 & 36 & 72.75 & 0.00 & 3.619 \\
\hline $642 \mathrm{~B}$ & $9 \mathrm{H}-05$ & 57 & 59 & 72.98 & 0.00 & 3.637 \\
\hline $642 B$ & $9 \mathrm{H}-05$ & 78 & 80 & 73.19 & 0.03 & 3.654 \\
\hline $642 B$ & $9 \mathrm{H}-05$ & 104 & 106 & 73.45 & 0.00 & 3.675 \\
\hline $642 B$ & $9 \mathrm{H}-05$ & 134 & 136 & 73.75 & 0.00 & 3.698 \\
\hline $642 \mathrm{~B}$ & $9 \mathrm{H}-06$ & 13 & 15 & 74.04 & 0.00 & 3.721 \\
\hline $642 \mathrm{~B}$ & $9 \mathrm{H}-06$ & 34 & 36 & 74.25 & 0.02 & 3.738 \\
\hline $642 \mathrm{~B}$ & $9 \mathrm{H}-06$ & 57 & 59 & 74.48 & 0.00 & 3.756 \\
\hline $642 \mathrm{~B}$ & $9 \mathrm{H}-06$ & 78 & 79 & 74.69 & 0.05 & 3.773 \\
\hline $642 \mathrm{~B}$ & $9 \mathrm{H}-06$ & 104 & 106 & 74.95 & 0.00 & 3.794 \\
\hline $642 \mathrm{~B}$ & $9 \mathrm{H}-06$ & 134 & 136 & 75.25 & 0.00 & 3.817 \\
\hline $642 \mathrm{~B}$ & $9 \mathrm{H}-07$ & 13 & 15 & 75.54 & 0.00 & 3.840 \\
\hline $642 \mathrm{~B}$ & $9 \mathrm{H}-07$ & 39 & 41 & 75.80 & 0.03 & 3.861 \\
\hline $642 \mathrm{~B}$ & $9 \mathrm{H}-07$ & 63 & 65 & 76.04 & 0.00 & 3.880 \\
\hline
\end{tabular}




\section{APPENDIX B}

Abundances (weight \%) of coarse-sand IRD in samples from ODP Hole $643 \mathrm{~A}$, with ages interpolated using constant sedimentation rates between paleomagnetic datums.

\begin{tabular}{|c|c|c|c|c|c|c|}
\hline Hole & Core & $\begin{array}{c}\text { Sample } \\
\text { top } \\
(\mathrm{cm})\end{array}$ & $\begin{array}{c}\text { Sample } \\
\text { base } \\
(\mathrm{cm})\end{array}$ & $\begin{array}{l}\text { Depth } \\
\text { (mbsf) }\end{array}$ & $\begin{array}{l}\text { IRD } \\
\text { wt } \%\end{array}$ & $\begin{array}{l}\text { Age } \\
\text { (Ma) }\end{array}$ \\
\hline $643 \mathrm{~A}$ & $1 \mathrm{H}-02$ & 5 & 7 & 1.56 & 2.97 & 0.043 \\
\hline $643 \mathrm{~A}$ & $1 \mathrm{H}-02$ & 54 & 56 & 2.05 & 0.9 & 0.056 \\
\hline $643 \mathrm{~A}$ & $1 \mathrm{H}-02$ & 88 & 90 & 2.39 & 0.97 & 0.066 \\
\hline $643 \mathrm{~A}$ & $1 \mathrm{H}-03$ & 31 & 33 & 3.32 & 0.38 & 0.091 \\
\hline $643 \mathrm{~A}$ & $1 \mathrm{H}-03$ & 67 & 69 & 3.68 & 1.49 & 0.101 \\
\hline $643 \mathrm{~A}$ & $2 \mathrm{H}-01$ & 89 & 91 & 6.20 & 3.68 & 0.170 \\
\hline $643 \mathrm{~A}$ & $2 \mathrm{H}-01$ & 145 & 147 & 6.76 & 0.99 & 0.186 \\
\hline $643 \mathrm{~A}$ & $2 \mathrm{H}-02$ & 14 & 16 & 6.95 & 0.38 & 0.191 \\
\hline $643 \mathrm{~A}$ & $2 \mathrm{H}-02$ & 89 & 91 & 7.70 & 0.1 & 0.212 \\
\hline $643 \mathrm{~A}$ & $2 \mathrm{H}-02$ & 145 & 147 & 8.26 & 3.75 & 0.227 \\
\hline $643 \mathrm{~A}$ & $2 \mathrm{H}-03$ & 14 & 16 & 8.45 & 1.01 & 0.232 \\
\hline $643 \mathrm{~A}$ & $2 \mathrm{H}-03$ & 89 & 91 & 9.20 & 0.84 & 0.253 \\
\hline $643 A$ & $2 \mathrm{H}-03$ & 145 & 147 & 9.76 & 1.08 & 0.268 \\
\hline $643 \mathrm{~A}$ & $2 \mathrm{H}-04$ & 14 & 16 & 9.95 & 0.46 & 0.273 \\
\hline $643 \mathrm{~A}$ & $2 \mathrm{H}-04$ & 89 & 91 & 10.70 & 1.02 & 0.294 \\
\hline $643 \mathrm{~A}$ & $2 \mathrm{H}-04$ & 138 & 140 & 11.19 & 4.01 & 0.307 \\
\hline $643 \mathrm{~A}$ & $2 \mathrm{H}-05$ & 14 & 16 & 11.45 & 0.77 & 0.315 \\
\hline $643 \mathrm{~A}$ & $2 \mathrm{H}-05$ & 89 & 91 & 12.20 & 0.48 & 0.335 \\
\hline $643 \mathrm{~A}$ & $2 \mathrm{H}-05$ & 146 & 148 & 12.77 & 0.03 & 0.351 \\
\hline $643 \mathrm{~A}$ & $2 \mathrm{H}-06$ & 89 & 91 & 13.70 & 0.24 & 0.376 \\
\hline $643 \mathrm{~A}$ & $2 \mathrm{H}-06$ & 145 & 147 & 14.26 & 0.97 & 0.392 \\
\hline $643 \mathrm{~A}$ & $2 \mathrm{H}-07$ & 14 & 16 & 14.45 & 0.42 & 0.397 \\
\hline $643 \mathrm{~A}$ & $3 \mathrm{H}-01$ & 36 & 38 & 14.17 & 0.25 & 0.417 \\
\hline $643 \mathrm{~A}$ & $3 \mathrm{H}-01$ & 79 & 81 & 15.60 & 3.33 & 0.429 \\
\hline $643 \mathrm{~A}$ & $3 \mathrm{H}-01$ & 129 & 131 & 16.10 & 2.53 & 0.442 \\
\hline $643 \mathrm{~A}$ & $3 \mathrm{H}-02$ & 36 & 38 & 16.67 & 0.53 & 0.458 \\
\hline $643 \mathrm{~A}$ & $3 \mathrm{H}-02$ & 72 & 74 & 17.03 & 1.13 & 0.468 \\
\hline $643 \mathrm{~A}$ & $3 \mathrm{H}-02$ & 129 & 131 & 17.60 & 6.17 & 0.484 \\
\hline $643 \mathrm{~A}$ & $3 \mathrm{H}-03$ & 36 & 38 & 18.17 & 0.15 & 0.499 \\
\hline $643 \mathrm{~A}$ & $3 \mathrm{H}-03$ & 72 & 74 & 18.53 & 0.08 & 0.509 \\
\hline $643 \mathrm{~A}$ & $3 \mathrm{H}-04$ & 36 & 38 & 19.67 & 1.09 & 0.540 \\
\hline $643 \mathrm{~A}$ & $3 \mathrm{H}-04$ & 72 & 74 & 20.03 & 0.07 & 0.550 \\
\hline $643 \mathrm{~A}$ & $3 \mathrm{H}-04$ & 129 & 131 & 20.60 & 0.54 & 0.566 \\
\hline $643 \mathrm{~A}$ & $3 \mathrm{H}-05$ & 36 & 38 & 21.17 & 0.69 & 0.582 \\
\hline $643 \mathrm{~A}$ & $3 \mathrm{H}-05$ & 72 & 74 & 21.53 & 0.11 & 0.591 \\
\hline $643 \mathrm{~A}$ & $3 \mathrm{H}-05$ & 129 & 131 & 22.10 & 1.09 & 0.607 \\
\hline $643 \mathrm{~A}$ & $3 \mathrm{H}-06$ & 36 & 38 & 22.67 & 0.16 & 0.623 \\
\hline $643 \mathrm{~A}$ & $3 \mathrm{H}-06$ & 72 & 74 & 23.03 & 0.39 & 0.633 \\
\hline $643 \mathrm{~A}$ & $3 \mathrm{H}-06$ & 129 & 131 & 23.60 & 0.39 & 0.648 \\
\hline $643 \mathrm{~A}$ & $3 \mathrm{H}-07$ & 45 & 47 & 24.26 & 1.64 & 0.666 \\
\hline $643 \mathrm{~A}$ & $4 \mathrm{H}-01$ & 28 & 30 & 24.59 & 0.09 & 0.676 \\
\hline $643 \mathrm{~A}$ & $4 \mathrm{H}-01$ & 84 & 86 & 25.15 & 0.12 & 0.691 \\
\hline $643 \mathrm{~A}$ & $4 \mathrm{H}-01$ & 132 & 134 & 25.63 & 0.34 & 0.704 \\
\hline $643 \mathrm{~A}$ & $5 \mathrm{H}-02$ & 28 & 30 & 26.09 & 0.41 & 0.717 \\
\hline $643 \mathrm{~A}$ & $4 \mathrm{H}-02$ & 84 & 86 & 26.65 & 0.44 & 0.735 \\
\hline $643 \mathrm{~A}$ & $4 \mathrm{H}-02$ & 132 & 134 & 27.13 & 0.25 & 0.760 \\
\hline $643 \mathrm{~A}$ & $4 \mathrm{H}-03$ & 28 & 30 & 27.59 & 0.34 & 0.785 \\
\hline $643 \mathrm{~A}$ & $4 \mathrm{H}-03$ & 84 & 86 & 28.15 & 1.81 & 0.815 \\
\hline $643 \mathrm{~A}$ & $4 \mathrm{H}-03$ & 132 & 134 & 28.63 & 1.05 & 0.840 \\
\hline $643 \mathrm{~A}$ & $4 \mathrm{H}-04$ & 28 & 30 & 29.09 & 0 & 0.865 \\
\hline $643 \mathrm{~A}$ & $4 \mathrm{H}-04$ & 84 & 86 & 29.65 & 1.07 & 0.894 \\
\hline $643 A$ & $4 \mathrm{H}-05$ & 28 & 30 & 30.59 & 3.41 & 0.938 \\
\hline $643 \mathrm{~A}$ & $4 \mathrm{H}-05$ & 84 & 86 & 31.15 & 1.35 & 0.942 \\
\hline $643 \mathrm{~A}$ & $4 \mathrm{H}-05$ & 132 & 134 & 31.63 & 1.15 & 0.956 \\
\hline $643 \mathrm{~A}$ & $4 \mathrm{H}-06$ & 28 & 30 & 32.09 & 0.51 & 0.968 \\
\hline $643 \mathrm{~A}$ & $4 \mathrm{H}-06$ & 84 & 86 & 32.65 & 1.74 & 0.982 \\
\hline $643 \mathrm{~A}$ & $4 \mathrm{H}-06$ & 132 & 134 & 33.13 & 0.46 & 0.995 \\
\hline $643 \mathrm{~A}$ & $4 \mathrm{H}-07$ & 34 & 36 & 33.65 & 0.61 & 1.009 \\
\hline $643 \mathrm{~A}$ & $5 \mathrm{H}-01$ & 28 & 30 & 34.09 & 1.41 & 1.021 \\
\hline $643 \mathrm{~A}$ & $5 \mathrm{H}-01$ & 90 & 92 & 34.71 & 0.37 & 1.038 \\
\hline $643 \mathrm{~A}$ & $5 \mathrm{H}-01$ & 126 & 128 & 35.07 & 1.58 & 1.048 \\
\hline $643 \mathrm{~A}$ & $5 \mathrm{H}-02$ & 28 & 30 & 35.59 & 2.29 & 1.062 \\
\hline $643 \mathrm{~A}$ & $5 \mathrm{H}-02$ & 90 & 92 & 36.21 & 0.53 & 1.079 \\
\hline $643 \mathrm{~A}$ & $5 \mathrm{H}-02$ & 126 & 128 & 36.57 & 0.34 & 1.088 \\
\hline
\end{tabular}




\section{APPENDIX C}

Abundances (weight \%) of coarse-sand IRD in samples from ODP Hole $644 \mathrm{~A}$, with ages interpolated using constant sedimentation rates between paleomagnetic datums.

\begin{tabular}{|c|c|c|c|c|c|c|}
\hline Hole & Core & $\begin{array}{c}\text { Sample } \\
\text { top } \\
(\mathrm{cm})\end{array}$ & $\begin{array}{c}\text { Sample } \\
\text { base } \\
(\mathrm{cm})\end{array}$ & $\begin{array}{l}\text { Depth } \\
\text { (mbsf) }\end{array}$ & $\begin{array}{l}\text { IRD } \\
\text { wt \% }\end{array}$ & $\begin{array}{l}\text { Age } \\
\text { (Ma) }\end{array}$ \\
\hline $644 \mathrm{~A}$ & $1 \mathrm{H}-01$ & 27 & 29 & 0.28 & 0.060 & 0.003 \\
\hline $644 \mathrm{~A}$ & $1 \mathrm{H}-01$ & 92 & 94 & 0.93 & 2.970 & 0.008 \\
\hline $644 \mathrm{~A}$ & $1 \mathrm{H}-01$ & 128 & 130 & 1.29 & 1.310 & 0.012 \\
\hline $644 \mathrm{~A}$ & $1 \mathrm{H}-02$ & 27 & 29 & 1.78 & 0.580 & 0.016 \\
\hline $644 \mathrm{~A}$ & $1 \mathrm{H}-02$ & 92 & 94 & 2.43 & 1.220 & 0.021 \\
\hline $644 \mathrm{~A}$ & $1 \mathrm{H}-02$ & 128 & 130 & 2.79 & 1.340 & 0.024 \\
\hline $644 \mathrm{~A}$ & $1 \mathrm{H}-03$ & 27 & 29 & 3.28 & 1.250 & 0.029 \\
\hline $644 \mathrm{~A}$ & $1 \mathrm{H}-03$ & 92 & 94 & 3.93 & 0.630 & 0.034 \\
\hline $644 \mathrm{~A}$ & $1 \mathrm{H}-03$ & 128 & 130 & 4.29 & 0.230 & 0.038 \\
\hline $644 \mathrm{~A}$ & $1 \mathrm{H}-04$ & 27 & 29 & 4.78 & 0.210 & 0.042 \\
\hline $644 \mathrm{~A}$ & $1 \mathrm{H}-04$ & 92 & 94 & 5.43 & 0.430 & 0.048 \\
\hline $644 \mathrm{~A}$ & $1 \mathrm{H}-04$ & 128 & 130 & 5.79 & 0.160 & 0.051 \\
\hline $644 \mathrm{~A}$ & $1 \mathrm{H}-05$ & 27 & 29 & 6.28 & 0.280 & 0.055 \\
\hline $644 \mathrm{~A}$ & $1 \mathrm{H}-05$ & 92 & 94 & 6.93 & 0.290 & 0.060 \\
\hline $644 \mathrm{~A}$ & $1 \mathrm{H}-05$ & 128 & 130 & 7.29 & 0.680 & 0.064 \\
\hline $644 \mathrm{~A}$ & $1 \mathrm{H}-06$ & 27 & 29 & 7.78 & 0.290 & 0.068 \\
\hline $644 \mathrm{~A}$ & $1 \mathrm{H}-06$ & 92 & 94 & 8.43 & 0.060 & 0.074 \\
\hline $644 \mathrm{~A}$ & $1 \mathrm{H}-06$ & 128 & 130 & 8.79 & 0.560 & 0.077 \\
\hline $644 \mathrm{~A}$ & $2 \mathrm{H}-01$ & 10 & 12 & 9.31 & 0.090 & 0.082 \\
\hline $644 \mathrm{~A}$ & $2 \mathrm{H}-01$ & 89 & 91 & 10.10 & 0.450 & 0.088 \\
\hline $644 \mathrm{~A}$ & $2 \mathrm{H}-01$ & 131 & 133 & 10.52 & 0.360 & 0.092 \\
\hline $644 \mathrm{~A}$ & $2 \mathrm{H}-02$ & 10 & 12 & 10.81 & 0.910 & 0.094 \\
\hline $644 \mathrm{~A}$ & $2 \mathrm{H}-02$ & 89 & 91 & 11.60 & 0.510 & 0.101 \\
\hline $644 \mathrm{~A}$ & $2 \mathrm{H}-02$ & 131 & 133 & 12.02 & 0.420 & 0.105 \\
\hline $644 \mathrm{~A}$ & $2 \mathrm{H}-03$ & 10 & 12 & 12.31 & 0.280 & 0.108 \\
\hline $644 \mathrm{~A}$ & $2 \mathrm{H}-03$ & 89 & 91 & 13.10 & 0.760 & 0.115 \\
\hline $644 \mathrm{~A}$ & $2 \mathrm{H}-03$ & 131 & 133 & 13.52 & 0.390 & 0.118 \\
\hline $644 \mathrm{~A}$ & $2 \mathrm{H}-04$ & 10 & 12 & 13.81 & 0.620 & 0.121 \\
\hline $644 \mathrm{~A}$ & $2 \mathrm{H}-04$ & 89 & 91 & 14.60 & 2.830 & 0.128 \\
\hline $644 \mathrm{~A}$ & $2 \mathrm{H}-04$ & 131 & 133 & 15.02 & 0.530 & 0.132 \\
\hline $644 \mathrm{~A}$ & $2 \mathrm{H}-05$ & 10 & 12 & 15.31 & 0.670 & 0.134 \\
\hline $644 \mathrm{~A}$ & $3 \mathrm{H}-01$ & 10 & 12 & 16.31 & 0.980 & 0.143 \\
\hline $644 \mathrm{~A}$ & $3 \mathrm{H}-01$ & 93 & 95 & 17.14 & 1.020 & 0.150 \\
\hline $644 \mathrm{~A}$ & $3 \mathrm{H}-01$ & 131 & 133 & 17.52 & 1.880 & 0.154 \\
\hline $644 \mathrm{~A}$ & $3 \mathrm{H}-02$ & 10 & 12 & 17.81 & 4.130 & 0.156 \\
\hline $644 \mathrm{~A}$ & $3 \mathrm{H}-02$ & 93 & 95 & 18.64 & 0.470 & 0.164 \\
\hline $644 \mathrm{~A}$ & $3 \mathrm{H}-02$ & 131 & 133 & 19.02 & 0.910 & 0.167 \\
\hline $644 \mathrm{~A}$ & $3 \mathrm{H}-03$ & 10 & 12 & 19.31 & 3.380 & 0.169 \\
\hline $644 \mathrm{~A}$ & $3 \mathrm{H}-03$ & 93 & 95 & 20.14 & 0.380 & 0.176 \\
\hline $644 \mathrm{~A}$ & $3 \mathrm{H}-04$ & 10 & 12 & 20.81 & 0.080 & 0.182 \\
\hline $644 \mathrm{~A}$ & $3 \mathrm{H}-04$ & 93 & 95 & 21.64 & 0.450 & 0.190 \\
\hline $644 \mathrm{~A}$ & $3 \mathrm{H}-04$ & 131 & 133 & 22.02 & 0.440 & 0.193 \\
\hline $644 \mathrm{~A}$ & $3 \mathrm{H}-05$ & 93 & 95 & 23.14 & 0.760 & 0.203 \\
\hline $644 \mathrm{~A}$ & $3 \mathrm{H}-05$ & 131 & 133 & 23.52 & 0.290 & 0.206 \\
\hline $644 \mathrm{~A}$ & $3 \mathrm{H}-06$ & 10 & 12 & 23.81 & 3.520 & 0.208 \\
\hline $644 \mathrm{~A}$ & $3 \mathrm{H}-07$ & 10 & 12 & 25.31 & 0.170 & 0.222 \\
\hline $644 \mathrm{~A}$ & $4 \mathrm{H}-01$ & 10 & 12 & 25.81 & 1.010 & 0.226 \\
\hline $644 \mathrm{~A}$ & $4 \mathrm{H}-01$ & 66 & 68 & 26.37 & 0.320 & 0.231 \\
\hline $644 \mathrm{~A}$ & $4 \mathrm{H}-01$ & 145 & 147 & 27.16 & 1.850 & 0.238 \\
\hline $644 \mathrm{~A}$ & $4 \mathrm{H}-02$ & 10 & 12 & 27.31 & 2.030 & 0.240 \\
\hline $644 \mathrm{~A}$ & $4 \mathrm{H}-02$ & 66 & 68 & 27.87 & 0.510 & 0.244 \\
\hline $644 \mathrm{~A}$ & $4 \mathrm{H}-02$ & 145 & 147 & 28.66 & 0.310 & 0.251 \\
\hline $644 \mathrm{~A}$ & $4 \mathrm{H}-03$ & 10 & 12 & 28.81 & 0.130 & 0.252 \\
\hline $644 \mathrm{~A}$ & $4 \mathrm{H}-03$ & 66 & 68 & 29.37 & 1.020 & 0.257 \\
\hline $644 \mathrm{~A}$ & $4 \mathrm{H}-03$ & 145 & 147 & 30.16 & 0.480 & 0.264 \\
\hline $644 \mathrm{~A}$ & $4 \mathrm{H}-04$ & 10 & 12 & 30.31 & 0.480 & 0.266 \\
\hline $644 \mathrm{~A}$ & $4 \mathrm{H}-04$ & 66 & 68 & 30.87 & 0.110 & 0.271 \\
\hline $644 \mathrm{~A}$ & $4 \mathrm{H}-04$ & 145 & 147 & 31.66 & 0.210 & 0.278 \\
\hline $644 \mathrm{~A}$ & $4 \mathrm{H}-05$ & 10 & 12 & 31.81 & 0.110 & 0.279 \\
\hline $644 \mathrm{~A}$ & $4 \mathrm{H}-05$ & 66 & 68 & 32.37 & 1.530 & 0.284 \\
\hline $644 \mathrm{~A}$ & $4 \mathrm{H}-05$ & 145 & 147 & 33.16 & 0.740 & 0.291 \\
\hline $644 \mathrm{~A}$ & $4 \mathrm{H}-06$ & 10 & 12 & 33.31 & 0.410 & 0.292 \\
\hline $644 \mathrm{~A}$ & $4 \mathrm{H}-06$ & 66 & 68 & 33.87 & 0.270 & 0.297 \\
\hline $644 \mathrm{~A}$ & $5 \mathrm{H}-01$ & 8 & 10 & 35.29 & 1.020 & 0.310 \\
\hline $644 \mathrm{~A}$ & $5 \mathrm{H}-01$ & 89 & 91 & 36.10 & 2.480 & 0.317 \\
\hline $644 \mathrm{~A}$ & $5 \mathrm{H}-02$ & 8 & 10 & 36.79 & 2.810 & 0.323 \\
\hline $644 \mathrm{~A}$ & $5 \mathrm{H}-02$ & 89 & 91 & 37.60 & 0.740 & 0.330 \\
\hline $644 A$ & $5 \mathrm{H}-02$ & 131 & 133 & 38.02 & 0.450 & 0.334 \\
\hline $644 \mathrm{~A}$ & $5 \mathrm{H}-03$ & 8 & 10 & 38.29 & 1.210 & 0.336 \\
\hline
\end{tabular}

Appendix C (continued).

\begin{tabular}{|c|c|c|c|c|c|c|}
\hline Hole & Core & $\begin{array}{c}\text { Sample } \\
\text { top } \\
(\mathrm{cm})\end{array}$ & $\begin{array}{c}\text { Sample } \\
\text { base } \\
(\mathrm{cm})\end{array}$ & $\begin{array}{l}\text { Depth } \\
\text { (mbsf) }\end{array}$ & $\begin{array}{l}\text { IRD } \\
\text { wt } \%\end{array}$ & $\begin{array}{l}\text { Age } \\
\text { (Ma) }\end{array}$ \\
\hline $644 \mathrm{~A}$ & $5 \mathrm{H}-03$ & 89 & 91 & 39.10 & 0.970 & 0.343 \\
\hline $644 \mathrm{~A}$ & $5 \mathrm{H}-03$ & 131 & 133 & 39.52 & 0.520 & 0.347 \\
\hline $644 \mathrm{~A}$ & $5 \mathrm{H}-04$ & 8 & 10 & 39.79 & 0.690 & 0.349 \\
\hline $644 \mathrm{~A}$ & $5 \mathrm{H}-04$ & 89 & 91 & 40.60 & 0.000 & 0.356 \\
\hline $644 \mathrm{~A}$ & $5 \mathrm{H}-04$ & 131 & 133 & 41.02 & 4.390 & 0.360 \\
\hline $644 \mathrm{~A}$ & $5 \mathrm{H}-05$ & 8 & 10 & 41.29 & 0.630 & 0.363 \\
\hline $644 \mathrm{~A}$ & $5 \mathrm{H}-05$ & 89 & 91 & 42.10 & 1.370 & 0.370 \\
\hline $644 \mathrm{~A}$ & $5 \mathrm{H}-05$ & 131 & 133 & 42.52 & 5.710 & 0.374 \\
\hline $644 \mathrm{~A}$ & $6 \mathrm{H}-01$ & 30 & 32 & 45.01 & 0.380 & 0.395 \\
\hline $644 \mathrm{~A}$ & $6 \mathrm{H}-01$ & 88 & 90 & 45.59 & 3.010 & 0.400 \\
\hline $644 \mathrm{~A}$ & $6 \mathrm{H}-01$ & 130 & 132 & 46.01 & 0.450 & 0.404 \\
\hline $644 \mathrm{~A}$ & $6 \mathrm{H}-02$ & 30 & 32 & 46.51 & 0.080 & 0.409 \\
\hline $644 \mathrm{~A}$ & $6 \mathrm{H}-02$ & 88 & 90 & 47.09 & 0.170 & 0.413 \\
\hline $644 \mathrm{~A}$ & $6 \mathrm{H}-02$ & 90 & 92 & 47.11 & 0.860 & 0.413 \\
\hline $644 \mathrm{~A}$ & $6 \mathrm{H}-02$ & 130 & 132 & 47.51 & 2.210 & 0.417 \\
\hline $644 \mathrm{~A}$ & $6 \mathrm{H}-03$ & 30 & 32 & 48.01 & 0.150 & 0.421 \\
\hline $644 \mathrm{~A}$ & $6 \mathrm{H}-03$ & 88 & 90 & 48.59 & 0.070 & 0.426 \\
\hline $644 \mathrm{~A}$ & $6 \mathrm{H}-03$ & 130 & 132 & 49.01 & 0.590 & 0.430 \\
\hline $644 \mathrm{~A}$ & $6 \mathrm{H}-04$ & 30 & 32 & 49.51 & 0.130 & 0.434 \\
\hline $644 \mathrm{~A}$ & $6 \mathrm{H}-04$ & 88 & 90 & 50.09 & 1.150 & 0.439 \\
\hline $644 \mathrm{~A}$ & $6 \mathrm{H}-05$ & 30 & 32 & 51.01 & 0.430 & 0.447 \\
\hline $644 \mathrm{~A}$ & $6 \mathrm{H}-05$ & 88 & 90 & 51.59 & 0.000 & 0.452 \\
\hline $644 \mathrm{~A}$ & $6 \mathrm{H}-05$ & 130 & 132 & 52.01 & 0.070 & 0.456 \\
\hline $644 \mathrm{~A}$ & $6 \mathrm{H}-06$ & 30 & 32 & 52.51 & 2.380 & 0.461 \\
\hline $644 \mathrm{~A}$ & $6 \mathrm{H}-06$ & 33 & 35 & 52.54 & 0.910 & 0.461 \\
\hline $644 \mathrm{~A}$ & $6 \mathrm{H}-06$ & 88 & 90 & 53.09 & 0.510 & 0.466 \\
\hline $644 \mathrm{~A}$ & $7 \mathrm{H}-01$ & 30 & 32 & 54.51 & 0.720 & 0.478 \\
\hline $644 \mathrm{~A}$ & $7 \mathrm{H}-01$ & 90 & 92 & 55.11 & 2.570 & 0.483 \\
\hline $644 \mathrm{~A}$ & $7 \mathrm{H}-01$ & 130 & 132 & 55.51 & 2.070 & 0.487 \\
\hline $644 \mathrm{~A}$ & $7 \mathrm{H}-02$ & 90 & 92 & 56.61 & 3.660 & 0.497 \\
\hline $644 \mathrm{~A}$ & $7 \mathrm{H}-02$ & 130 & 132 & 57.01 & 4.180 & 0.500 \\
\hline $644 \mathrm{~A}$ & $7 \mathrm{H}-03$ & 130 & 132 & 58.51 & 0.490 & 0.514 \\
\hline $644 \mathrm{~A}$ & $7 \mathrm{H}-04$ & 30 & 32 & 59.01 & 0.120 & 0.518 \\
\hline $644 A$ & $5 \mathrm{H}-04$ & 90 & 92 & 59.61 & 0.160 & 0.524 \\
\hline $644 \mathrm{~A}$ & $7 \mathrm{H}-\mathrm{CC}$ & 30 & 32 & 63.66 & 4.850 & 0.558 \\
\hline $644 \mathrm{~A}$ & $8 \mathrm{H}-01$ & 30 & 32 & 64.01 & 1.040 & 0.561 \\
\hline $644 \mathrm{~A}$ & $8 \mathrm{H}-01$ & 113 & 115 & 64.84 & 0.350 & 0.569 \\
\hline $644 \mathrm{~A}$ & $8 \mathrm{H}-02$ & 20 & 22 & 65.41 & 0.220 & 0.574 \\
\hline $644 \mathrm{~A}$ & $8 \mathrm{H}-02$ & 130 & 132 & 66.51 & 1.130 & 0.583 \\
\hline $644 \mathrm{~A}$ & $8 \mathrm{H}-03$ & 30 & 32 & 67.01 & 0.250 & 0.587 \\
\hline $644 \mathrm{~A}$ & $8 \mathrm{H}-03$ & 90 & 92 & 67.61 & 1.230 & 0.593 \\
\hline $644 \mathrm{~A}$ & $8 \mathrm{H}-03$ & 130 & 132 & 68.01 & 0.190 & 0.596 \\
\hline $644 \mathrm{~A}$ & $8 \mathrm{H}-04$ & 30 & 32 & 68.51 & 0.170 & 0.601 \\
\hline $644 \mathrm{~A}$ & $8 \mathrm{H}-05$ & 30 & 32 & 70.01 & 1.710 & 0.614 \\
\hline $644 \mathrm{~A}$ & $8 \mathrm{H}-05$ & 90 & 92 & 70.61 & 1.340 & 0.620 \\
\hline $644 \mathrm{~A}$ & $8 \mathrm{H}-05$ & 130 & 132 & 71.01 & 0.130 & 0.623 \\
\hline $644 \mathrm{~A}$ & $9 \mathrm{H}-01$ & 30 & 32 & 73.51 & 0.160 & 0.645 \\
\hline $644 \mathrm{~A}$ & $9 \mathrm{H}-01$ & 65 & 67 & 73.86 & 0.000 & 0.648 \\
\hline $644 \mathrm{~A}$ & $9 \mathrm{H}-01$ & 98 & 100 & 74.19 & 0.010 & 0.651 \\
\hline $644 \mathrm{~A}$ & $9 \mathrm{H}-02$ & 30 & 32 & 75.01 & 0.220 & 0.658 \\
\hline $644 \mathrm{~A}$ & $9 \mathrm{H}-02$ & 65 & 67 & 75.36 & .0520 & 0.661 \\
\hline $644 \mathrm{~A}$ & $9 \mathrm{H}-02$ & 98 & 100 & 75.69 & 0.520 & 0.664 \\
\hline $644 \mathrm{~A}$ & $9 \mathrm{H}-03$ & 30 & 32 & 76.51 & 0.000 & 0.672 \\
\hline $644 \mathrm{~A}$ & $9 \mathrm{H}-03$ & 65 & 67 & 76.86 & 0.020 & 0.674 \\
\hline $644 \mathrm{~A}$ & $9 \mathrm{H}-03$ & 98 & 100 & 77.19 & 0.010 & 0.677 \\
\hline $644 \mathrm{~A}$ & $9 \mathrm{H}-04$ & 30 & 32 & 78.01 & 0.070 & 0.684 \\
\hline $644 \mathrm{~A}$ & $9 \mathrm{H}-04$ & 65 & 67 & 78.36 & 0.260 & 0.687 \\
\hline $644 \mathrm{~A}$ & $9 \mathrm{H}-04$ & 98 & 100 & 78.69 & 0.910 & 0.690 \\
\hline $644 \mathrm{~A}$ & $9 \mathrm{H}-05$ & 30 & 32 & 79.51 & 0.320 & 0.698 \\
\hline $644 \mathrm{~A}$ & $9 \mathrm{H}-05$ & 65 & 67 & 79.86 & 1.080 & 0.700 \\
\hline $644 \mathrm{~A}$ & $9 \mathrm{H}-05$ & 98 & 100 & 80.19 & 0.260 & 0.703 \\
\hline $644 \mathrm{~A}$ & $10 \mathrm{H}-01$ & 30 & 32 & 83.01 & 0.430 & 0.728 \\
\hline $644 \mathrm{~A}$ & $10 \mathrm{H}-01$ & 88 & 90 & 83.59 & 0.950 & 0.733 \\
\hline $644 \mathrm{~A}$ & $10 \mathrm{H}-01$ & 130 & 132 & 84.01 & 0.250 & 0.737 \\
\hline $644 \mathrm{~A}$ & $10 \mathrm{H}-02$ & 30 & 32 & 84.51 & 0.070 & 0.741 \\
\hline $644 \mathrm{~A}$ & $10 \mathrm{H}-02$ & 88 & 90 & 85.09 & 0.010 & 0.756 \\
\hline $644 \mathrm{~A}$ & $10 \mathrm{H}-02$ & 130 & 132 & 85.51 & 0.010 & 0.750 \\
\hline $644 \mathrm{~A}$ & $10 \mathrm{H}-03$ & 30 & 32 & 86.01 & 0.000 & 0.754 \\
\hline $644 \mathrm{~A}$ & $10 \mathrm{H}-03$ & 88 & 90 & 86.59 & 0.150 & 0.760 \\
\hline
\end{tabular}


Appendix C (continued).

\begin{tabular}{|c|c|c|c|c|c|c|}
\hline Hole & Core & $\begin{array}{c}\text { Sample } \\
\text { top } \\
\text { (cm) }\end{array}$ & $\begin{array}{c}\text { Sample } \\
\text { base } \\
(\mathrm{cm})\end{array}$ & $\begin{array}{l}\text { Depth } \\
\text { (mbsf) }\end{array}$ & $\begin{array}{l}\text { IRD } \\
\text { wt } \%\end{array}$ & $\begin{array}{l}\text { Age } \\
\text { (Ma) }\end{array}$ \\
\hline $644 \mathrm{~A}$ & $10 \mathrm{H}-03$ & 130 & 132 & 87.01 & 0.470 & 0.763 \\
\hline $644 \mathrm{~A}$ & $10 \mathrm{H}-04$ & 30 & 32 & 87.51 & 0.010 & 0.768 \\
\hline $644 \mathrm{~A}$ & $10 \mathrm{H}-04$ & 88 & 90 & 88.09 & 0.720 & 0.773 \\
\hline $644 \mathrm{~A}$ & $10 \mathrm{H}-04$ & 130 & 132 & 88.51 & 1.520 & 0.776 \\
\hline $644 \mathrm{~A}$ & $10 \mathrm{H}-05$ & 30 & 32 & 89.01 & 0.110 & 0.781 \\
\hline $644 \mathrm{~A}$ & $10 \mathrm{H}-06$ & 30 & 32 & 90.51 & 0.660 & 0.794 \\
\hline $644 \mathrm{~A}$ & $11 \mathrm{H}-01$ & 30 & 32 & 92.51 & 0.370 & 0.811 \\
\hline $644 \mathrm{~A}$ & $11 \mathrm{H}-01$ & 90 & 92 & 93.11 & 0.190 & 0.817 \\
\hline $644 \mathrm{~A}$ & $11 \mathrm{H}-01$ & 130 & 132 & 93.51 & 0.170 & 0.820 \\
\hline $644 \mathrm{~A}$ & $11 \mathrm{H}-02$ & 30 & 32 & 94.01 & 0.160 & 0.825 \\
\hline $644 \mathrm{~A}$ & $11 \mathrm{H}-02$ & 90 & 92 & 94.61 & 0.820 & 0.830 \\
\hline $644 \mathrm{~A}$ & $11 \mathrm{H}-02$ & 130 & 132 & 95.01 & 0.030 & 0.833 \\
\hline $644 \mathrm{~A}$ & $11 \mathrm{H}-03$ & 30 & 32 & 95.51 & 0.320 & 0.838 \\
\hline $644 \mathrm{~A}$ & $11 \mathrm{H}-03$ & 90 & 92 & 96.11 & 1.110 & 0.843 \\
\hline $644 \mathrm{~A}$ & $11 \mathrm{H}-03$ & 130 & 132 & 96.51 & 0.530 & 0.846 \\
\hline $644 \mathrm{~A}$ & $11 \mathrm{H}-04$ & 30 & 32 & 97.01 & 0.320 & 0.851 \\
\hline $644 \mathrm{~A}$ & $11 \mathrm{H}-04$ & 90 & 92 & 97.61 & 0.510 & 0.856 \\
\hline $644 \mathrm{~A}$ & $11 \mathrm{H}-04$ & 130 & 132 & 98.01 & 1.470 & 0.860 \\
\hline $644 \mathrm{~A}$ & $11 \mathrm{H}-05$ & 30 & 32 & 98.51 & 1.310 & 0.864 \\
\hline $644 \mathrm{~A}$ & $11 \mathrm{H}-05$ & 90 & 92 & 99.11 & 0.880 & 0.869 \\
\hline $644 \mathrm{~A}$ & $11 \mathrm{H}-05$ & 130 & 132 & 99.51 & 0.060 & 0.873 \\
\hline $644 \mathrm{~A}$ & $11 \mathrm{H}-06$ & 30 & 32 & 100.01 & 0.560 & 0.877 \\
\hline $644 \mathrm{~A}$ & $11 \mathrm{H}-06$ & 90 & 92 & 100.61 & 0.000 & 0.882 \\
\hline $644 \mathrm{~A}$ & $11 \mathrm{H}-06$ & 130 & 132 & 101.01 & 0.260 & 0.886 \\
\hline $644 \mathrm{~A}$ & $12 \mathrm{H}-01$ & 30 & 32 & 102.01 & 0.630 & 0.895 \\
\hline $644 \mathrm{~A}$ & $12 \mathrm{H}-01$ & 90 & 92 & 102.61 & 0.790 & 0.900 \\
\hline $644 \mathrm{~A}$ & $12 \mathrm{H}-01$ & 130 & 132 & 103.01 & 0.000 & 0.904 \\
\hline $644 \mathrm{~A}$ & $12 \mathrm{H}-02$ & 30 & 32 & 103.51 & 0.730 & 0.908 \\
\hline $644 \mathrm{~A}$ & $12 \mathrm{H}-02$ & 90 & 92 & 104.11 & 0.060 & 0.913 \\
\hline $644 \mathrm{~A}$ & $12 \mathrm{H}-02$ & 130 & 132 & 104.51 & 0.000 & 0.917 \\
\hline $644 \mathrm{~A}$ & $12 \mathrm{H}-03$ & 30 & 32 & 105.01 & 0.080 & 0.921 \\
\hline $644 \mathrm{~A}$ & $12 \mathrm{H}-03$ & 90 & 92 & 105.61 & 0.150 & 0.927 \\
\hline $644 \mathrm{~A}$ & $12 \mathrm{H}-03$ & 130 & 132 & 106.01 & 0.010 & 0.931 \\
\hline $644 \mathrm{~A}$ & $12 \mathrm{H}-04$ & 30 & 32 & 106.51 & 0.000 & 0.936 \\
\hline $644 \mathrm{~A}$ & $12 \mathrm{H}-04$ & 90 & 92 & 107.11 & 0.010 & 0.941 \\
\hline $644 \mathrm{~A}$ & $12 \mathrm{H}-05$ & 30 & 32 & 108.01 & 1.450 & 0.950 \\
\hline $644 \mathrm{~A}$ & $12 \mathrm{H}-05$ & 90 & 92 & 108.61 & 0.060 & 0.955 \\
\hline $644 \mathrm{~A}$ & $12 \mathrm{H}-05$ & 130 & 132 & 109.01 & 0.610 & 0.959 \\
\hline $644 \mathrm{~A}$ & $12 \mathrm{H}-06$ & 30 & 32 & 109.51 & 0.000 & 0.964 \\
\hline $644 \mathrm{~A}$ & $12 \mathrm{H}-06$ & 90 & 92 & 110.11 & 0.000 & 0.970 \\
\hline $644 \mathrm{~A}$ & $12 \mathrm{H}-06$ & 130 & 132 & 110.51 & 0.000 & 0.973 \\
\hline $644 \mathrm{~A}$ & $12 \mathrm{H}-07$ & 30 & 32 & 111.01 & 0.080 & 0.978 \\
\hline $644 \mathrm{~A}$ & $13 \mathrm{H}-01$ & 30 & 32 & 111.51 & 0.000 & 0.984 \\
\hline $644 \mathrm{~A}$ & $13 \mathrm{H}-01$ & 90 & 92 & 112.11 & 0.000 & 0.991 \\
\hline $644 \mathrm{~A}$ & $13 \mathrm{H}-01$ & 130 & 132 & 112.51 & 0.060 & 0.996 \\
\hline $644 \mathrm{~A}$ & $13 \mathrm{H}-02$ & 30 & 32 & 113.01 & 0.830 & 1.002 \\
\hline $644 \mathrm{~A}$ & $13 \mathrm{H}-02$ & 130 & 132 & 114.01 & 0.040 & 1.014 \\
\hline $644 \mathrm{~A}$ & $13 \mathrm{H}-03$ & 30 & 32 & 114.51 & 0.610 & 1.021 \\
\hline $644 \mathrm{~A}$ & $13 \mathrm{H}-03$ & 90 & 92 & 115.11 & 0.350 & 1.028 \\
\hline $644 \mathrm{~A}$ & 13H-04 & 30 & 32 & 116.01 & 0.040 & 1.039 \\
\hline $644 \mathrm{~A}$ & $13 \mathrm{H}-04$ & 90 & 92 & 116.61 & 0.390 & 1.047 \\
\hline $644 \mathrm{~A}$ & $13 \mathrm{H}-04$ & 130 & 132 & 117.01 & 0.380 & 1.051 \\
\hline $644 \mathrm{~A}$ & $13 \mathrm{H}-05$ & 30 & 32 & 117.51 & 1.170 & 1.058 \\
\hline $644 \mathrm{~A}$ & $13 \mathrm{H}-05$ & 90 & 92 & 118.11 & 1.250 & 1.065 \\
\hline $644 \mathrm{~A}$ & $13 \mathrm{H}-06$ & 30 & 32 & 119.01 & 0.000 & 1.076 \\
\hline $644 \mathrm{~A}$ & $13 \mathrm{H}-06$ & 90 & 92 & 119.61 & 0.000 & 1.084 \\
\hline $644 \mathrm{~A}$ & $13 \mathrm{H}-07$ & 30 & 32 & 120.51 & 0.220 & 1.095 \\
\hline $644 \mathrm{~A}$ & $13 \mathrm{H}-07$ & 90 & 92 & 121.11 & 0.010 & 1.102 \\
\hline $644 \mathrm{~A}$ & $13 \mathrm{H}-07$ & 130 & 132 & 121.51 & 0.040 & 1.107 \\
\hline $644 \mathrm{~A}$ & $14 \mathrm{H}-01$ & 31 & 33 & 121.02 & 0.080 & 1.101 \\
\hline $644 \mathrm{~A}$ & $14 \mathrm{H}-01$ & 95 & 97 & 121.66 & 0.030 & 1.109 \\
\hline $644 \mathrm{~A}$ & $14 \mathrm{H}-02$ & 95 & 97 & 123.16 & 0.740 & 1.127 \\
\hline $644 \mathrm{~A}$ & $14 \mathrm{H}-02$ & 131 & 133 & 123.52 & 0.310 & 1.132 \\
\hline $644 \mathrm{~A}$ & $14 \mathrm{H}-03$ & 31 & 33 & 124.02 & 0.050 & 1.138 \\
\hline $644 \mathrm{~A}$ & $14 \mathrm{H}-03$ & 95 & 97 & 124.66 & 0.220 & 1.146 \\
\hline $644 \mathrm{~A}$ & $14 \mathrm{H}-04$ & 31 & 33 & 125.52 & 0.410 & 1.157 \\
\hline $644 \mathrm{~A}$ & $14 \mathrm{H}-04$ & 95 & 97 & 126.16 & 0.000 & 1.164 \\
\hline $644 \mathrm{~A}$ & 14H-05 & 31 & 33 & 127.02 & 0.070 & 1.175 \\
\hline $644 \mathrm{~A}$ & $14 \mathrm{H}-05$ & 95 & 97 & 127.66 & 0.050 & 1.183 \\
\hline $644 \mathrm{~A}$ & $14 \mathrm{H}-05$ & 131 & 133 & 128.02 & 0.330 & 1.187 \\
\hline
\end{tabular}

